\title{
The Intimacy of Paul to the Thessalonians in 1Thess. 2: 7b-12
}

\author{
Sotirios Despotis ${ }^{*}$ \\ Department of Social Theology of Athens University \\ sotdespo@yahoo.gr
}

\begin{abstract}
Sotirios Despotis, Bliskość Pawła wobec Tesaloniczan w 1 Tes 2,7b-12, Elpis, 16 2014: 99-111.
Abstract: In one of the earliest documents of Christianity, in a highly patriarchal society, when addressing Gentile Christians, Paul did not hesitate to liken himself not only to a father, but also to a woman who cares for her own children. In contrast to itinerant philosophers, he did not only preach, but by the example of his life showed love for them, even to the point of sacrificing his being. The metaphor of the mother relates among other things with the admonition to avoid prostitution and the koinonia of all during and after the Last Judgment.

In the oldest document of Christianity, Paul speaks to Christians of all nations and does not stop, in a upmost Patriarchal society, trying to assimilate himself with the image of a woman in the way she nurtures and cares for her own children. He does not simply preach, but unlike the wandering philosophers, he has such calmness, compassion and love for them in which he gives his soul, his being. Simultaneously, he is a father, since with his example and sayings, he teaches everyone, individually, to stay away from iniquity and prays unceasingly. The presentation of the sender as a mother and father of the recipients, brothers of the newborn Church of Thessaloniki, relates to the call to stay away from harlotry and that everybody will coexist during and after the Second Coming of our Lord. Translation by: Nikolaos Georgantonis
\end{abstract}

\begin{abstract}
Streszczenie: W jednym z najstarszych dokumentów chrześcijaństwa, w bardzo patriarchalnym społeczeństwie, apostoł Paweł zwracając się do Chrześcijan z pogan, nie waha się upodobnić nie tylko do ojca, ale także kobiety, która jako niania dba o własne dzieci. W przeciwieństwie do wędrownych filozofów, apostoł Paweł nie tylko nauczał słowem, lecz i przykładem swojego życia ukazywał łagodność, dobroczynność i miłość, ofiarowując swoją duszę i życie. Metafora matki związana jest między innymi z upomnieniem, aby unikać prostytucji i tworzyć wspólnotę wszystkich w trakcie życia doczesnego i po Sądzie Ostatecznym.

W najstarszym dokumencie chrześcijaństwa, Paweł mówi do chrześcijan wszystkich narodów, nie zatrzymuje się na społeczeństwie patriarchalnym, lecz stara się zasymilować z obrazem kobiety - piastunki, i tak jak ona karmić i troszczyć się o własne dzieci. On nie tylko głosił, ale w przeciwieństwie do wędrujących filozofów, miał taki spokój, współczucie i miłość do tych ludzi, dla których oddawał swoją duszę i całe swoje istnienie. Jednocześnie, ukazuje się w postaci ojca, ponieważ jego przykład i słowa, uczyły wszystkich, indywidualnie, pozostawania z dala od nieprawości i nieustannej modlitwy. Prezentacja autora listu jako matki i ojca odbiorców, braci rodzącego się Kościoła w Salonikach, związane jest w związane było z wezwaniem do pozostawiania z dala od nierządu, i skłonienia adresatów do zgodnego współistnienia we wspólnocie zarówno przed, jaki i po drugim przyjściu naszego Pana.
\end{abstract}

Keywords: beneficent nurse, intimacy, benevolence, metaphor

Słowa kluczowe: dobroczynny opiekun, intymność, życzliwość, metafora

\section{Introduction}

On the parent-child metaphors/Eikóvec ${ }^{1}$ in 1 Thess. with which Paul seeks to bind his "children" to himself in a special way, focus two studies: (a) T.J. Burke in his $A$ Socio-Historical Study of Kinship Metaphors in 1 Thessalonians, London 2003 investigates the role of the parents in the graeco-roman literature and accordingly in the oldest

\footnotetext{
Sotiris Despotis was born in Athens in 1968. He studied Theology at the university of Athens. After his postgraduate in Germany (Mainz), he was awarded a Doctor of Philosophy. The title of his doctoral thesis was The Heavenly Worship in John's Revelation, Chapters 4-5. In 2009 he was elected as Associate Prof. of the Department of Social Theology of Athens University. His object of research is the Interpretation of New Testament.

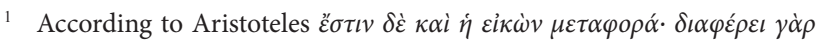

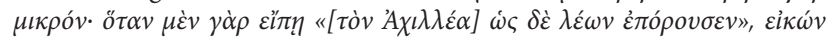

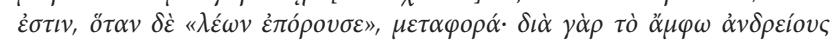

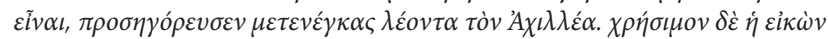

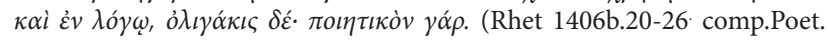

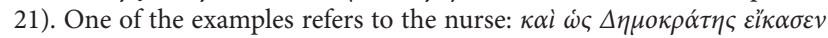

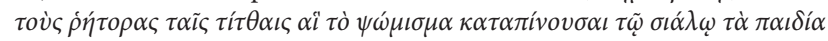
$\pi \alpha \rho \alpha \lambda \varepsilon i \varphi$ ov
}

epistle of Paul'2. (b) Christine Gerber in her Paulus und seine ,Kinder. Studien zur Beziehungsmetaphorik der paulinischen Briefe $\left(2005^{3}\right)$ dedicates the chapter 6 to Paulus

\footnotetext{
2 As Burke states, the father-son relationship obeys to the hierarchypyramid reason which portrays the first as the object of obedience and imitation by the second. The father offered love and teaching although there was a distinction between the tenderness of the nurse and fatherly love. See also Paul's Role as 'Father' to his Corinthian 'Children' in SocioHistorical Context (1 Cor. 4:14-21). Paul and the Corinthians: Studies on a Community in Conflict. Essays in Honour of Margaret Thrall. Supplements to Novum Testamentum, (ed. Trevor J. Burke and J. Keith Elliott). Leiden: Brill Academic Publishers, 2003 95-113 - Adopted into God's Family: Exploring a Pauline Metaphor. New Studies in Biblical Theology 22. Downers Grove: InterVarsity Press, 2006.-Adopted as Sons: The Missing Piece in Pauline Soteriology.

3 Beihefte zur Zeitschrift für die Neutestamentliche Wissenschaft BZNW 136 Berlin-New York: Walter de Gruyter. The history of exegesis possibly starts with F. Zimmer,I Thess. 2, 3-8 erklärt.Theologische Studien Herrn ... Professor D. Bernard Weiss zu seinem 70. Geburtstage dargebracht. Göttingen: Vandenhoeck \& Ruprecht, 1897, 248-273. In the greek

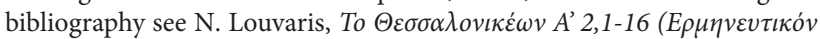

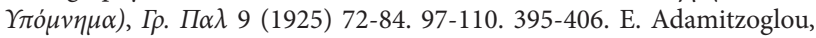

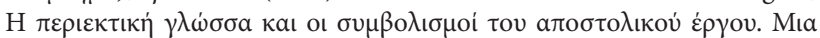

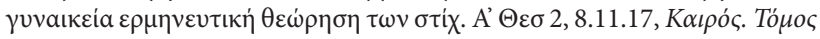


als Vater und Mutter einer neuen Familie (1 Thes. 2, 7-12. 17-20). Die Bedeutung der Missionare für die Gemeinde von Thessalinoch in der Konstruktion des Briefes ${ }^{4}$.

In this exposition I will examine (1) the structure of the Section 2:7b-13 and the rhetoric strategy of Paul, (2) the meaning and the purpose of the comparison of the apostle with nurse and father, (3) the behavior of the itinerant philosophers in the graeco-roman world, (4) his intimacy with Thessalonians in the Makrotext of the epistle and (5) the reasons for this behavior.

\section{Section $2: 7 b-13$}

The first part of the 1 Thes. (ch. 1-3) $)^{5}$ is divided into two sections: in the first the crucial time of the election $(1: 8)$ is recalled, in which the receivers were initiated into Christianity from Paul and his associates $(1: 4-2: 13)^{6}$ and in the second what has happened from the past to the present $(2: 14-3: 13)^{7}$. Paul uses domestic pictures like that of the nurse and the father in the third subunit of the first section, which (section) has the following structure:

1. 1: 4-8: God's election and dynamic influence of the Pauline word. The audience's ethos (captatio benevolentiae $\left.{ }^{8}\right)$.

2. 1: 9-10: Content of the Gospel (Return to the living and true God + Second Coming of his Son whom He raised from the dead - Jesus, who rescues us from the coming wrath).

3. 2: 1-13: Preacher's ethos. In this subunit Paul follows the chiastic structure:

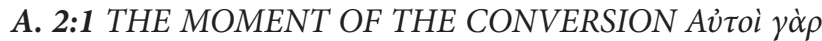

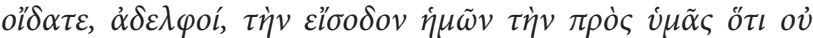

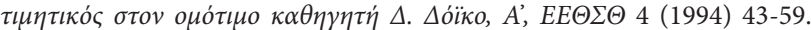

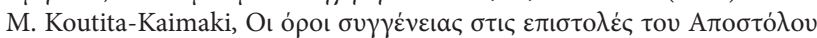

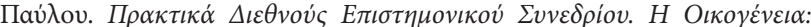

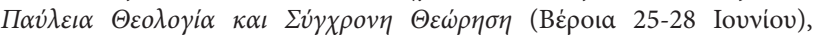
Beroia 2009 167-188. For Paul as instructor-paidagogos see A. Bitaskis,

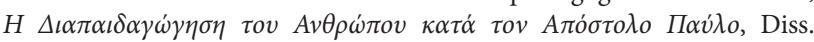
Athens 2005.

4 From the history of exegesis (p. 36-8) it is distinguished B.R. Gaventa, Apostles as Babes and Nurses in 1 Thessalonians 2:7, Faith and History (FS P.W. Meyer) J.T. Carol ... (ed.), Atlanta 1990 193-207.

The second part is exhortation and is divided in sections which start

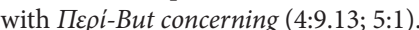

${ }^{6}$ Reminding the former-beginning status of the audience is a standard practice in Pauline epistles so as to correct their beliefs and practices and also to remind them of his apostolic stature. Oddly enough it is not mentioned the baptism as happens with the eucharist too.

This succession of the time is combined with motion in the field of the

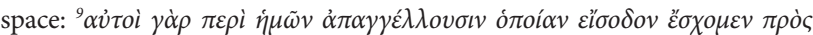

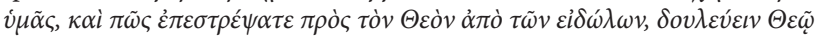

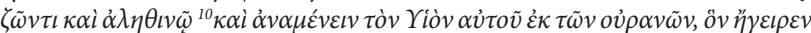
$\dot{\varepsilon} \kappa[\tau \tilde{\omega} v] v \varepsilon \kappa \rho \tilde{\omega} v(1: 9-10)$. The result of this $\dot{\varepsilon} \pi \iota \sigma \tau \rho o \varphi \dot{\eta}$ and the equivalent $\pi \varepsilon \rho i \pi \alpha \tau o \varsigma$ (4:1) are described in the precedent vers: $\dot{\alpha} \varphi^{\prime} \dot{v} \mu \tilde{\omega} v \gamma \dot{\alpha} \rho \dot{\varepsilon} \xi \dot{\eta} \chi \eta \tau \alpha \iota \dot{o}$

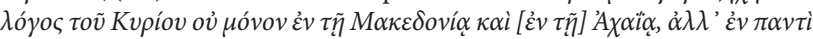

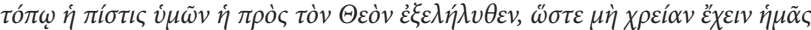
$\lambda \alpha \lambda \varepsilon \tilde{\varepsilon} v \tau \iota$ (1:8). In the chap. 3 the motion refers to the effort of the apostle to bridge the distance between him and the Thessalonians.

8 From the 3:10 we conclude that the pistis of the receivers wasn't so perfect as it supposed in the 1:3.

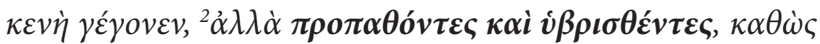

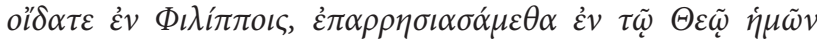

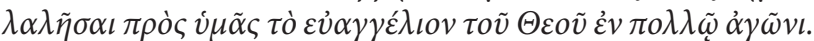

B. "VERBAL TRANSMISSION" - CHARACTERISTICS

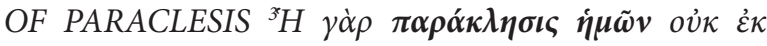

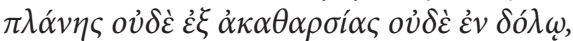

C. BEHAVIOR OF THE APOSTLES ${ }^{4} \dot{\alpha} \lambda \lambda \dot{\alpha} \kappa \alpha \theta \dot{\omega} \varsigma$

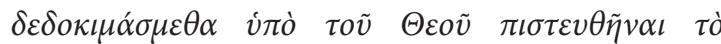

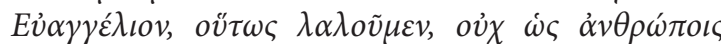

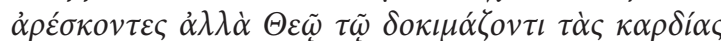

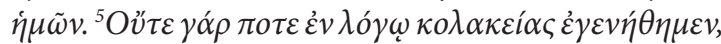

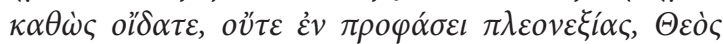

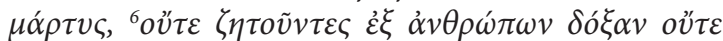

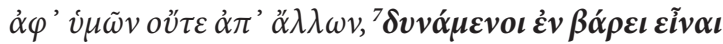

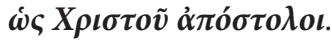

D. TRANSMISSION OF LIFE 'A $\lambda \lambda \dot{\alpha} \varepsilon \dot{\varepsilon} \gamma \varepsilon v \dot{\theta} \theta \eta \mu \varepsilon v$

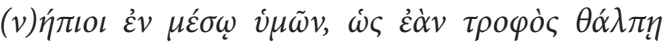

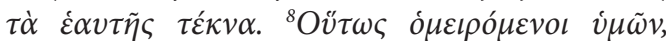

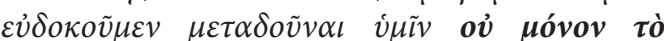

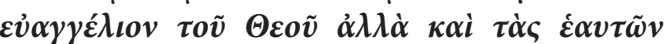

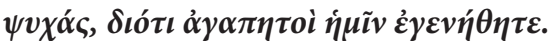

$C^{\prime \prime}$. BEHAVIOR OF THE APOSTLES ${ }^{9}$ Mv

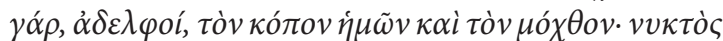

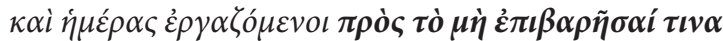

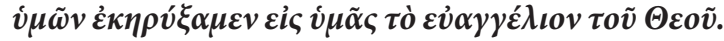
B'. "VERBAL TRANSMISSION" - CHARACTERIS-

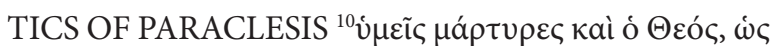

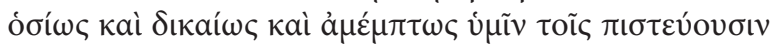

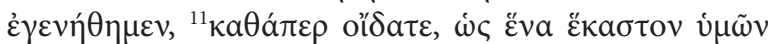

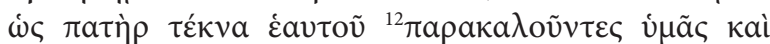

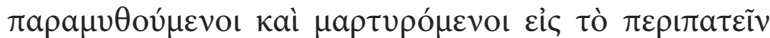

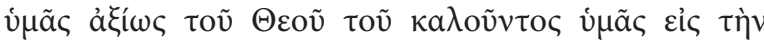

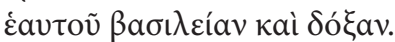

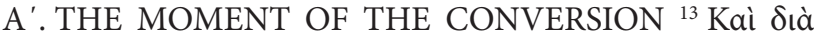

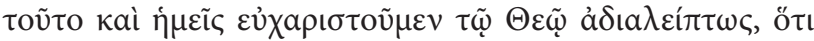

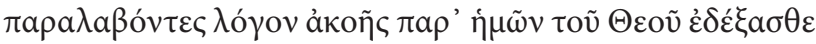

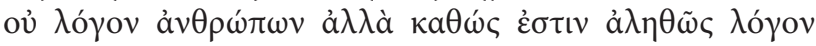

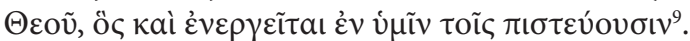

The first conclusion is that the image of the nurse who cares for her own children constitutes the heart of the third subunit which is as well located in the core of the first section of the entire epistle. This part, distinguished for its well-done chiastic structure, exposes the status and personal ethos of the apostles towards the Thessalonians from the beginning until that time. The question is why Paul projects by this way his ethos and the one of the Gospel. The answer is essential to decode the meaning and the intention of the metaphors. From the epilogue of the first section and principally of the one of the entire epistle, we

\footnotetext{
9 With A' he recalls simultaneously the initial praise of his work (1:2) in

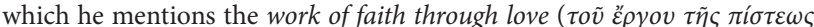

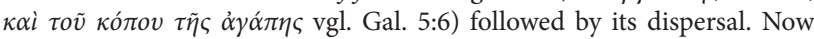
in this second mention he speaks of the work of God's word within the audience, as they received God's word from us (Paul and associates)- $\pi \alpha \rho$ ' $\dot{\eta} \mu \tilde{\omega} v \tau o v \Theta \varepsilon o v$. The word of God works within those who continue to believe (not just those who believed) to which the writer refers in plural (in you).
} 
conclude that one of the main targets of the 1 Thes. is the following: all ${ }^{10}$ the brothers and sisters Thessalonians to be wholly sanctified and their spirit (higher mental functions), soul (lower mental functions) ${ }^{11}$ and body preserved blameless at the coming of the Lord Jesus Christ with all his saints. This goal however presupposes trust in the word of Paul and fides/fidelity to his person and his motives. The confidence by the Thessalonians in him and his word is according to 3:6 high. For some ólıyouv́xovৎ (feebleminded 5:14) however the trust must had been shaken through the afflictions, his bodily absence, the delay of the Parousia, the death of some brothers etc. For this reason it is important for him to strengthen first the bond between him and his entire audience and then to start the exhor-

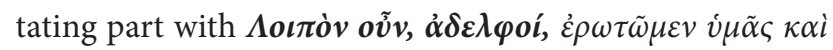
$\pi \alpha \rho \alpha \kappa \alpha \lambda o \tilde{v} \mu \varepsilon v \dot{\varepsilon} v \kappa v \rho i \omega^{\prime} I \eta \sigma o \tilde{v}, i v \alpha \kappa \alpha \theta \dot{\omega} \varsigma \pi \alpha \rho \varepsilon \lambda \alpha \dot{\alpha} \beta \varepsilon \tau \varepsilon \pi \alpha \rho$ '

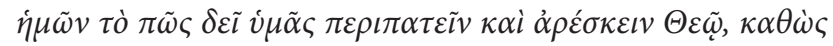

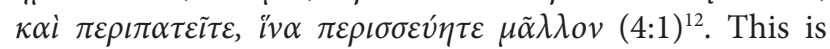
why Paul follows the strategy of deliberative rhetoric ${ }^{13}$ with elements of the epideictic one. $\mathrm{He}$ (1) uses captatio benevolentiae, (2) remindes the Gospel and its energy and (3) emphasizes the ethos of him (the sender) and his Gospel using as core the Verses v. $7 \mathrm{~b}-8$ where he proclaims his maternal feelings!

The abovementioned conclusions are strengthened by the linguistic-syntactic analysis of the entire first section (1:4-2:13):

1. The emphasis to the drastic action (power and energy) of the verbal message of the apostles despite the $\theta \lambda i \psi \varepsilon \varepsilon \varsigma$ is proved by the frequent use of the following words: (i) the gospel/evayyélıov (2:4) solely/ $\boldsymbol{\eta} \boldsymbol{\mu} \tilde{\boldsymbol{\omega}} \boldsymbol{v}$-our (1:4)/ $\boldsymbol{\tau o} \tilde{\boldsymbol{v}} \boldsymbol{\Theta} \boldsymbol{\varepsilon} \boldsymbol{\varepsilon} \tilde{\boldsymbol{v}}$-of God (2:2) which is object of $\lambda \alpha \lambda \varepsilon \tilde{\varepsilon} v / \kappa \eta \rho \dot{\tau} \tau \varepsilon l v$ and the consequence of

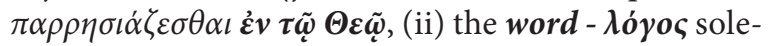

\footnotetext{
10 As the Apostle emphatically states at the end of the epistle, this letter must be read to all the holy brethren.

11 F.F. Bruce: 1 and 2 Thessalonians (electronic ed.).Word Biblical Commentary Vol. 45: Logos Library System; Word Biblical Commentary. Dallas: Word, Incorporated, ad loc.

12 We should underline that a lot of the subjects that Paul ascribes to himself are later advised in the exhortating section: action not out of uncleanness, work and pray night and day, love of the brothers, dearly praying without ceasing and rejoicing in spite of the persecutions.

13 From the abovementioned I believe that the main scopus of the epistle is paraenetic and refers to the future (Second Parousia), elements which are the characteristics of deliberative genus. According to Aristoteles in this genus the Orator must defend his ethos which also happens

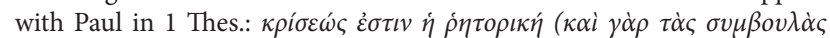

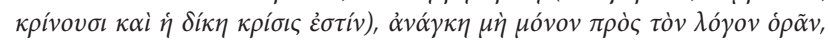

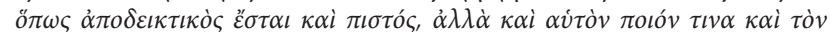

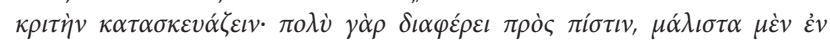

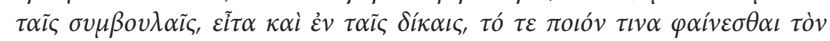

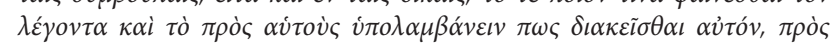

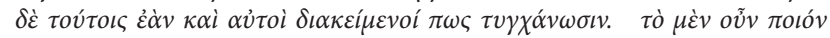

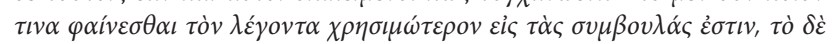

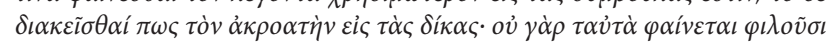

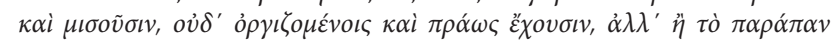

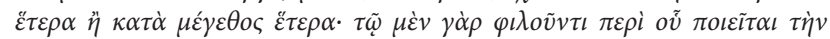

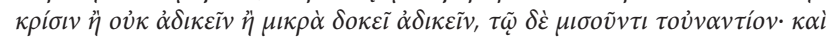

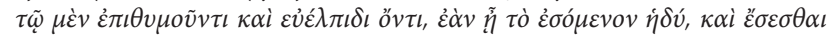

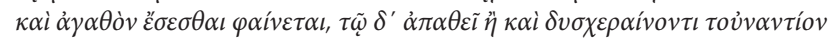
(Rhet 1377b.21 -1378a.5).
}

ly (1:6)/of the Lord (2:8) and (iii) П $\boldsymbol{\alpha} \rho \dot{\alpha} \boldsymbol{\kappa} \lambda \eta \sigma \iota \varsigma$ (2:3) as comfort (apparently because it rescues from the wrath) and exhortation ${ }^{14}$. If the meaning of the Gospel is so important, the question ${ }^{15}$ is why then Paul in v. $7 \mathrm{~b}-8$ desires to transmit not only this but also his psyche to the recipients. Is the Gospel not sufficient to strengthen the brothers and sisters at Thessaloniki in the present? The core of Pauls' argumentation about his ethos, however, refers not only to the past but to the present and the future as well ${ }^{16}$. The same verb $\mu \varepsilon \tau \alpha \delta o \tilde{v} v \alpha \iota$ is used by him in Rom. 1:11 where he expresses the same wish for communication face to face. The object, however, is the $\chi^{\alpha} \rho \imath \sigma \mu \alpha$ because the receivers aren't familiar with him. Therefore by the verses 1 Thes. 2:7b-8 he doesn't relativiert the value of his Gospel but (a) he expresses his extreme love which isn't limited in the orally teaching (which suits to an apostle of a Kyrios who has died for us 5:10) and (b) he prepares his audience for the following section of his epistle which expresses his desire for personal communication. In any case the inhalt both of the pauline Gospel and the psyche was the same: Jesus Christ and his Spirit.

2. Frequent is also the use of the lexems oi $\delta \alpha \tau \varepsilon-k n o w^{17}$ and yive $\sigma \theta \alpha \iota$ (1:5-7 [3X]; 2:1.5.7.8.10.14) in the past tense. The first verb has as subject the ífĩc/you and the second apart from four times $(1: 6-7 ; 2: 8.14)^{18}$ the apostles and the characteristics of their preaching as they appeared during their first entry ( the city. Therefore as witnesses to testify the allegations of Paul are mentioned not only God (v. 2:5b.10) but also the epistle receivers themselves, who are named

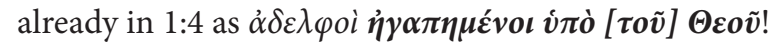
(see also 2:1.9.14) ${ }^{19}$. This means that the author probably defends himself and his word against derogatory comments and/or accusations which are emanated not from insiders but rather from outsiders: either from the compatriots of Thessalonians (2:14) or generally

14 This is transcribed in 2:11-12 like this: as you know how we exhorted, and comforted, and charged every one of you, as a father does his own children, that you would walk worthy of God. The same kind of words he

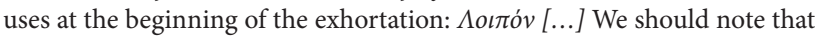

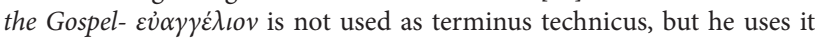
literally as the use of the verb ev่ $\alpha \gamma \gamma \varepsilon \lambda i \sigma \alpha \sigma \theta \alpha$-bring good news/ evangelize (3:6) proves.

15 See Gerber, Paulus und seine, Kinder' 277.

16 The members of the chiasmus, which refer to the past, run supplementally: B and C express negatively what B' and C' declare positively.

17 M. Crüsemann, Die pseudepigraphen Briefe an die Gemeinde in Thessaloniki: Studien zu ihrer Abfassung und zur jüdisch-christlichen Sozialgeschichte, Stuttgart 2010, 130-137.

18 The subject in these verses is the Thessalonians and the main motif is the mimesis.

19 Paul doesn't hesitate to boost the Thessalonians' self-confidence in 4:9 also with: But concerning brotherly love you have no need that I should write to you, for you yourselves are taught by God to love one another and ${ }^{2} \alpha \dot{\tau} \tau o i$ $\gamma \dot{\alpha} \rho \dot{\alpha} \kappa \rho \iota \beta \tilde{\omega} \varsigma$ olı $\alpha \tau \varepsilon-F o r$ you yourselves know perfectly (5:2). By this way the apostle shows that he faces the recipients not as immature children but reliable witnesses who remember and know. Maybe Paul feels that their self-confidence is a way of resistance to the disgrace of their environment. 
from the Greek environment where Paul declares the gospel of $\operatorname{God}^{20}$. At any case through the reminding of these $\pi i \sigma \tau \varepsilon l \varsigma$ (proofs/convictions) of the past, he does strengthen the confidence of these insiders who need encouragement and identity markers. For this reason

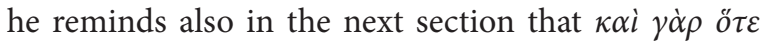

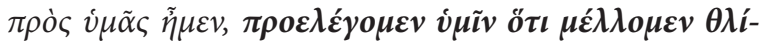

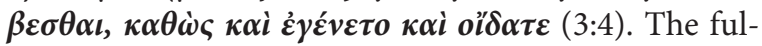
fillment of a prophecy was a pistis with high importance in ancient rhetoric ${ }^{21}$.

3. The $\pi i \sigma \tau \varepsilon l \varsigma$ are strengthened by using negative cause + $(\dot{\alpha} \lambda \lambda \grave{\alpha} /$ but $)+$ thesis $+\kappa a \theta \omega \dot{c} /$ as:

a. 1:5: For our gospel did not come to you in word only, but also i) in power, and ii) in the Holy Spirit and iii) in much $\pi \lambda \eta \rho о \varphi о \rho i \alpha^{22}$, as you know what kind of men we were among you for your sake

b. 2:1-2: our coming to you was not in vain. ${ }^{2}$ But... we were bold in our God to speak to you the gospel of God in much conflict

c. 2:3-8: For our exhortation did not come from i) error or ii) uncleanness, nor was it iii) in deceit. ${ }^{4}$ But as we have been approved by God to be entrusted with the gospel, even so we speak, not as pleasing men, but God who tests our hearts.

${ }^{5}$ For neither at any time did we i) use flattering words, as you know, nor ii) with a pretext for greed-God is witness. ${ }^{6}$ Nor did we iii) seek glory from men, either from you or from others, when we might have made demands as apostles of Christ. ${ }^{7}$ But we were gentle among you, just as a nursing mother cherishes her own children. ${ }^{8}$ So, affectionately longing for you, we were well pleased to impart to you not only the gospel of God, but also our own lives, because you had become dear to us.

The use of negative cause differentiate the apostles and their message against the teaching of the various itinerant philosophers who were passing from Thessaloniki self-promoted as doctors of the souls ${ }^{23}$ : the Gospel of the apostles

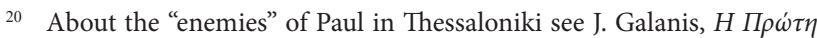

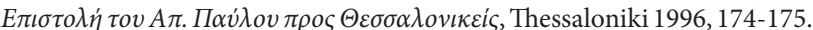
The Question of the Exegesis remains the following: The discussion has revolved in part around the question whether vss- 1-12 are to be understood as an apology directed to a concrete situation in Thessalonica in the face of which Paul had to defend himself, or whether the language that seems to support such a view can be understood in another way. A major statement in favor of the latter option had been made by VON DOBSCHÜTZ, who claimed that the "apology" reflects the mood of Paul at the time of writing rather than a strained relationship with the Thessalonians (A.J. Malherbe 'Gentle as a Nurse': The Stoic Background to 1 Thess. II. NovT 12 (1970) 203-217. 203)

21 W. Kurz, Hellenistic Rhetoric in the Christological Proof of Luke-Acts, CBQ 42 (1980) 171-195, 187-188.

22 I believe that this doesn't mean only the assurance (Heb. 10:22) but has also the meaning of the abundance of the fruits of the Holy Spirit which brings xapá despite the sorrows. It has to do with the work of faith, labor of love, and endurance of hope in our Lord Jesus Christ (1:3). By this way the message of God works effectively in you believers (2:1)

23 The expression comes from Leveque: «Un médecin de l' âme chez les Grecs», Revue des Deux Mondes, 1867, 725.
}

didn't come in word only (1:5), the entry of them wasn't vain (2:1: $\kappa \varepsilon v \eta^{24}$; comp. 3:5) while the Paraclese of theirs didn't come from i) error ii) uncleanness iii) in deceit. In 2:10 Paul expresses the same things positively: $\dot{\omega} \varsigma \delta \sigma i ́ \omega \varsigma \kappa \alpha i$

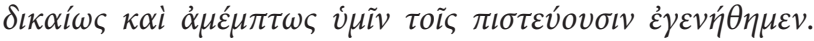
With $\boldsymbol{\pi} \boldsymbol{\lambda} \boldsymbol{\alpha} \boldsymbol{v} \boldsymbol{\eta} /$ error and $\boldsymbol{\alpha} \boldsymbol{\alpha} \boldsymbol{\alpha} \boldsymbol{\theta} \boldsymbol{\alpha} \boldsymbol{\rho} \boldsymbol{\sigma} \boldsymbol{\alpha} \boldsymbol{\alpha} /$ uncleanness Paul probably means failure in dogma (doctrine about God) for the first and the interactive failure in ethical conduct for the second ${ }^{25}$. With $\varepsilon v$ $v o ́ \lambda \omega /$ In deceit ${ }^{26}$ he refers to the motive of preaching, that is why it is presented with $\dot{\varepsilon} v / i n . \Delta$ ó $\mathrm{o} \varsigma^{27} /$ Deceit is linked with the use of $\boldsymbol{i}$ ) flattering words ii) greed-

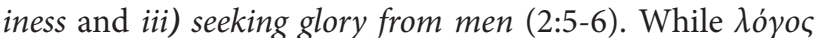
$\kappa o \lambda \alpha \kappa \varepsilon i \alpha \varsigma^{28} /$ flattering words is linked to the previous v.4b

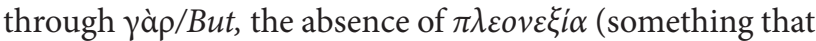
God is called upon to testify! $)^{29}$ and of the the desire of glory are connected with the following phrase: $\delta$ vvá $\mu \varepsilon v o$ c $\dot{\varepsilon} v$

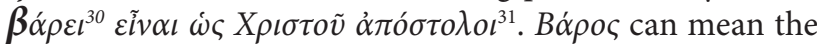
financial charge (comp. $\dot{\varepsilon} \pi \iota \beta \alpha \rho \tilde{\eta} \sigma \alpha \iota$ of v. 2:9; 2Thes. 3:8) and/or having honor (2 Cor. 4:17). Both of them were acclaimed not only by the supposedly philosophers but also by the legati of Caesar who used also the theme of Angaria (compulsory service). The agents of the Arisen from Hades, who comes as the True Kyrios from Heaven introducing his own Kingdom-Imperium and glory, could not only be supported by other Christians (as stated in 1 Cor. 9; 2 Cor. 11-12 and Luk. 10:7) but they could also acclaim hon-

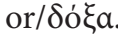

\section{Paul as a beneficent nurse and father}

Paul culminates his argumentation with $\dot{\alpha} \lambda \lambda \dot{\alpha} \dot{\varepsilon} \gamma \varepsilon$ $v \dot{\eta} \theta \eta \mu \varepsilon v(v) \eta \dot{\eta} \pi \iota$ c $\dot{\varepsilon} v \boldsymbol{\mu} \varepsilon \boldsymbol{\varepsilon} \boldsymbol{\omega} \dot{\boldsymbol{v}} \boldsymbol{\mu} \tilde{\boldsymbol{\omega}} \boldsymbol{v}$ to support that he selected the completely opposite style of $\dot{\varepsilon} v \beta \dot{\alpha} \rho \varepsilon \varepsilon$ Eivo $\alpha$ (which presupposes something/someone that is above us)! ${ }^{32}$ The problems with this phrase are the following: a) did the original text have $\dot{\eta} \pi \iota \varsigma$ or $v \dot{\eta} \pi \iota \varsigma$-child according to Nestle

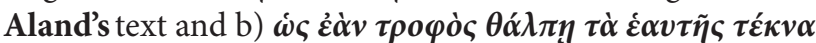

\footnotetext{
24 About the meaning of кعvó see Gerber, Paulus und seine 'Kinder' 271 Anm. 81

25 As it is showed in Rom. 1-2 (also see Sap. 13-15) for him these two are interacted.

26 At this point in the Greek text the writer might be engaging in a

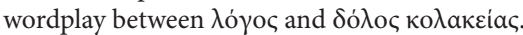

$27<$ indogerm. del= intent

28 It is related with $\kappa \eta \lambda \dot{\varepsilon} \omega=$ bewitch, fascinate / $\kappa \dot{\varepsilon} \lambda \lambda \omega=$ motivate, encourage.

$29<\pi \rho \circ \varphi$ ai $v \omega=$ bring in the light, appear, obvious motiv.

30 The consonants $\delta$ and $\beta$ transmit also soundly the elements of $\delta$ v́va $\mu$,

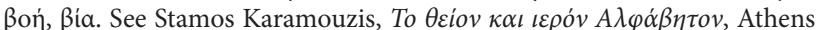
2001264.282.

31 The term $\beta \dot{\alpha} \rho \circ /$ burden connected to demands as apostles of Christ can refer to glory but also to the financial burden of their support. V.9

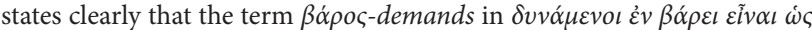
X mean the burden of their financial support.

32 We have already seen that v. $2: 7 \mathrm{~b}-8$ constitute the heart of the argumentation in the entire 2:1-13.
} 
should be connected with v. $7 b^{33}$ or v. $\mathbf{8}^{34}$ as Nestle Aland's text suggests contrary to its own previous edition?

Child- $v \dot{\eta} \pi \iota \varsigma^{35}$ means $\dot{\alpha} v \dot{\omega} \rho \iota \mu о \varsigma$-immature, $\ddot{\alpha} \varphi \rho \omega v^{36}$ -imbecile while $\ddot{\eta} \pi \iota \circ$ ( $<$ ancient Hindu api-friend) is the meek, the content and the good willed ${ }^{37}$. The form $v \dot{\eta} \pi \iota \varsigma^{38}$

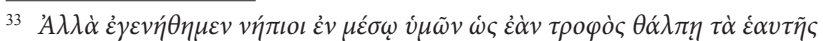

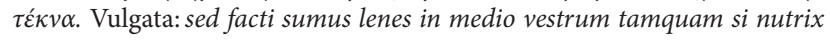
foveat filios suos. MGI (=Peschita Translation by Janet Magiera 2006): ${ }^{7} \mathrm{But}$ we were meek among you, and as a nurse who loves her children. Luther 45: sondern wir sind mütterlich gewesen bei euch, gleichwie eine Amme ihrer

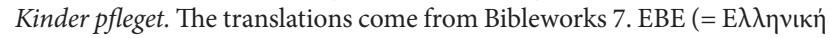

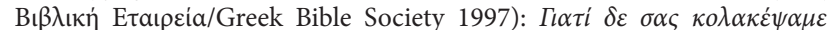

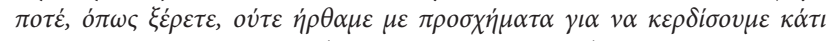

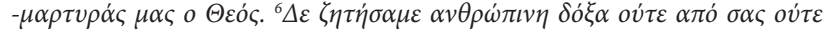

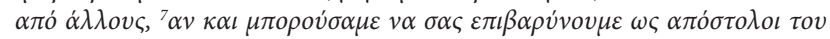
X

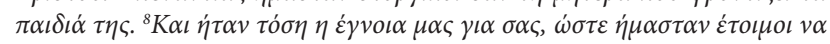

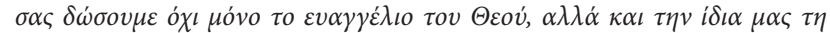
$\zeta \omega \dot{\eta}^{\prime}, \varepsilon \pi \varepsilon l \delta \dot{\eta} \sigma \alpha \varsigma \alpha \gamma \alpha \pi \dot{\eta} \sigma \alpha \mu \varepsilon$.
}

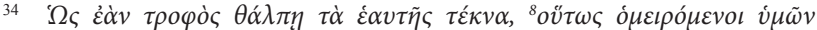

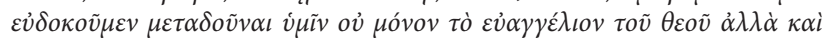

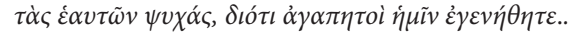

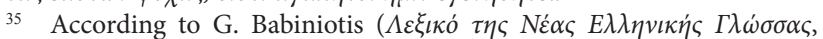

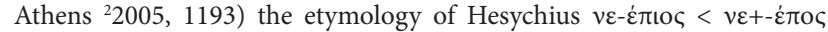
= who can't speak normally ( $v \eta \pi \dot{\tau} \tau i o \varsigma)$ but also the connection with $\eta \dot{\eta} \pi \dot{\omega} \omega=$ call, isn't supported by strong arguments. Clement of Alexandria, $\Pi \alpha \iota \delta \alpha \omega \gamma \gamma \varsigma^{\prime} 1.5 .19$ makes a false etymology too, possibly in his struggle against those who mocked Christians as foolish: 'Ev ${ }^{\prime} \alpha \tilde{v} \theta \alpha \dot{\varepsilon} \pi \iota \sigma \tau \tilde{\eta} \sigma \alpha \iota$

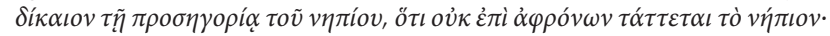

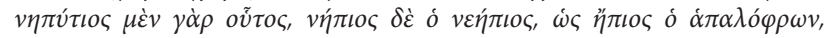
oĩov $\eta^{\pi} \pi ı$

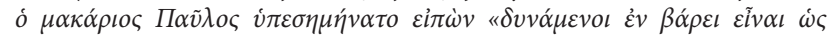
X

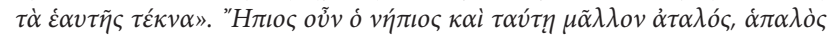

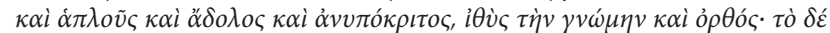

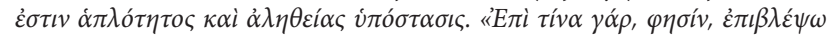

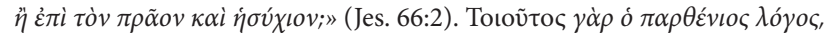

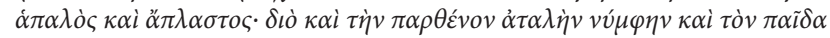

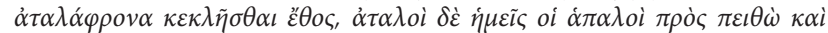

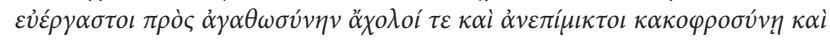
$\sigma \kappa o \lambda \iota o ́ \tau \eta \tau \iota$.Also the etymology is unknown.

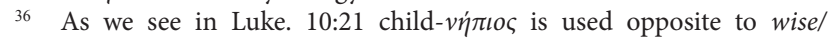
intelligent, while in Rom. 2:10 the word is used for proselytes. In Gal. 4: 1-3 and Eph. 4: 14 the author calls the receivers juveniles and the Corinthians (1 Cor. 3:1 see also Heb. 5:12-14) as well during their early days as Christians especially since they were quarreling: And I, brethren, could not speak to you as to spiritual people but as to carnal, as to babes in Christ. ${ }^{2}$ I fed you with milk and not with solid food; for until now you were not able to receive it, and even now you are still not able; ${ }^{3}$ or you are still carnal. For where there are envy, strife, and divisions among you, are you not carnal and behaving like mere men? Even to this day the young Christian is a juvenile in mind by standards of faith: When I was a child, I spoke as a child, I understood as a child, I thought as a child; but when I became a man, I put away childish things (1 Cor. 13:11). Brethren, do not be children in understanding; however, in malice be babes, but in understanding be mature (1 Cor. 14: 20). In any occasion the word child is connected to the lack of knowledge.

37 See Henry George Liddell - Robert Scott, A Greek-English Lexicon, http://www.perseus.tufts.edu/hopper/ text?doc=Perseus:text: 1999.04.0057, ad loc.

38 There is a strongly attested variant vทं $\operatorname{ciol}$ ("infants") read by $\mathrm{P}^{65} \mathrm{~N}^{*} \mathrm{~B}$

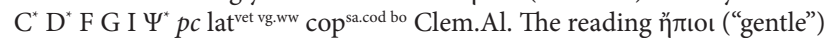
is attested by $\aleph^{c} \mathrm{~A} \mathrm{C}^{2} \mathrm{D}^{2} \Psi^{\mathrm{c}}$ Byz latt ${ }^{\mathrm{vg} . \mathrm{st}}$ cop $^{\text {sa.codd }}$ The variation is due either to haplography or dittography of $v$. It is the sense that is decisive for $\eta^{\prime \prime} \pi \mathrm{lol}$,

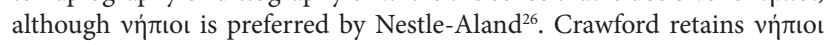
but construes it as vocative, addressed to the Thessalonian Christians. C. Crawford, "The 'Tiny' Problem of 1 Thessalonians 2, 7: The case of the curious vocative." Bib 54 (1973) 69-72. See the critic of F.F. Bruce, 1 and 2 Thessalonians Logos Library System; Word Biblical Commentary (1998). Vol. 45. Dallas: Word, Incorporated. (electronic ed.). is the oldest one yet not the most difficult as we will explain further. Maybe the reason for its establishment is not just Dittography but also the following influence of the synoptic tradition which is visible also in 5:2-339:

1. The child version in conjunction with the demand for glory, recalls to the copyists the answer of Jesus in Mark 9:33-37 (= Mt. 18:1-5; Lk. 9:46-48; John 3:3.5; 13:20) on the way to Passion: ${ }^{33}$ Then He came to Capernaum. And when He was in the house He asked them, "What was it you disputed among yourselves on the road?" ${ }^{44}$ But they kept silent, for on the road they had disputed among themselves who would be the greatest. ${ }^{35}$ And He sat down, called the twelve, and said to them, "If anyone desires to be first, he shall be last of all and servant of all." ${ }^{36}$ Then He took a little child and set him in the midst of them. And when He had taken him in His arms, He said to them, ${ }^{37}$ "Whoever receives one of these little children in My name receives $\mathrm{Me}$; and whoever receives $\mathrm{Me}$, receives not Me but Him who sent Me. " A child is presented as the model for the apostles, one being that by society standards and Jewish Law, is meaningless, immature and imbecile. Paul did the same with his own disciples ${ }^{40}$.

2. The seventy apostles in Luke $10: 21(\mathrm{Q}=$ Mt. 11:2527) cause rejoice to Jesus who thanks the Father because contrary to the wise and intelligent they are like infants who receive divine revelations: In that hour Jesus rejoiced in the Spirit and said, "I thank You, Father, Lord of heaven and earth, that You have hidden these things from the wise and prudent and revealed them to babies. Even so, Father, for so it seemed good in Your sight. Here we have rejoice, thankfulness and revelation, elements that we also meet in 1 Thess.

Besides, as Paul presents the figure of the father and son (which seems to be implied through the use of

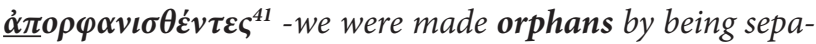
rated from you) intertwining to one another, so it is possible for some copyists that the milk giving nurse/mother ${ }^{42}$ and child figure also coexist. Then however before $v \eta^{\prime} \pi \iota$ - -child

\section{See Holtzt, Der erste Brief an die Thessalonicher, 215-219.}

40 Origenes (Commentarium in evangelium Matthaei lib. 12-17) in

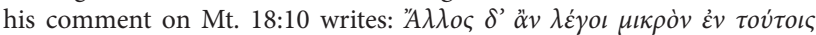

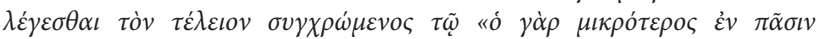

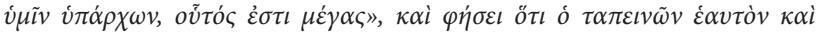

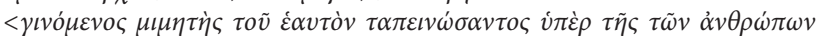

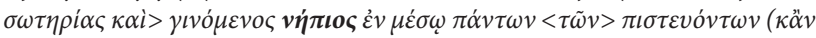

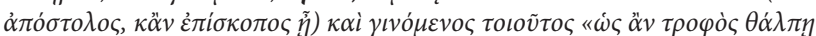

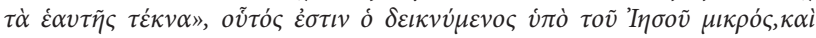

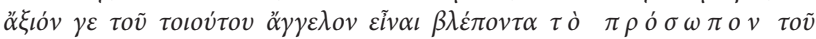

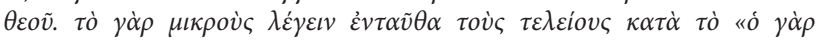

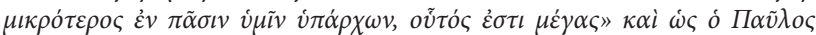

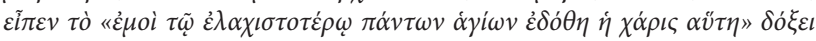

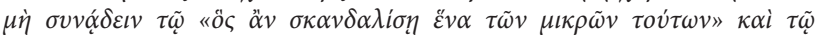

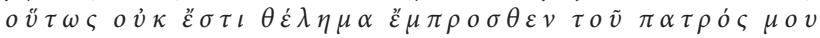

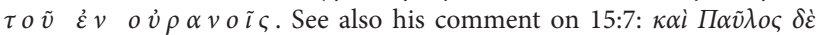

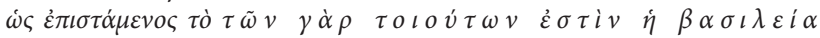

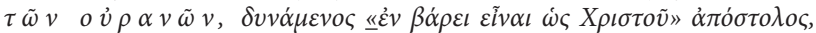

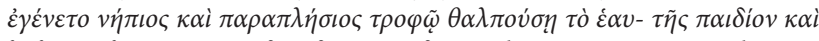

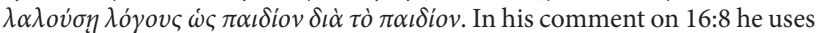

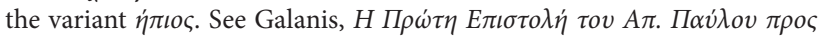

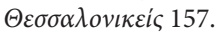

41 ö $\rho$

42 A nurse so eager to sacrifice her own life proves that this nurse is also a mother. The same occurred with the Son, the coming Judge, who died for us according to 5:10. 
there should have been $\dot{\omega} \varsigma$-like, as there is with the nurse and father figure. Moreover as Caragounis ${ }^{43}$ proves, the greek $\dot{\boldsymbol{\alpha}} \boldsymbol{\pi} \boldsymbol{\rho} \rho \varphi \boldsymbol{\alpha} v \boldsymbol{v} \boldsymbol{\sigma} \theta \dot{\boldsymbol{\varepsilon}} \boldsymbol{v} \tau \varepsilon \boldsymbol{\varepsilon}$ - made orphans may not only refer to the loss of parents but also to that of children.

For the reasons above, we prefer the word $\ddot{\eta} \pi l o \varsigma$ which also appears in 2 Tim. 2:24-25 as opposite to quarrelsome, referring to Christian leaders: And a servant of the Lord must not quarrel but be gentle to all, able to teach, patient, in humility correcting those who are in opposition, if God perhaps will grant them repentance, so that they may know the truth ${ }^{44}$. But the term $\ddot{\eta} \pi$ io does not have the aforementioned meaning in our passage since it is used against ambition and greediness ${ }^{45}$. For this reason I don't agree as well with A.J. Malherbe ${ }^{46}$ who suggests that the $\dot{\eta} \pi i o ́ \tau \eta \varsigma$ to which the writer appeals here, forms a designed contrast to

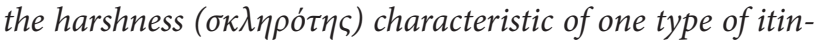
erant Cynic, who could not distinguish scurrilous reproach

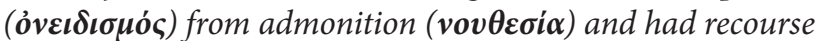
to the former when the latter was required (Dio, Oratio 32).

To understand the complete meaning of term $\eta \pi$ io must investigate its use in Homer where it refers to the ideal Leader and the effecthistory (Wirkungsgeschichte) of this

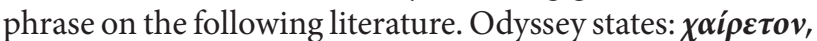

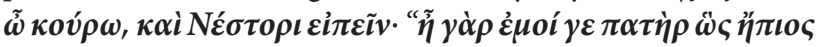

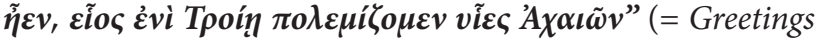
to you, lads, and tell king Nestor this: he was like a gentle father to me for as long as we Achaioi-Greeks were fighting in Troy; 15 [o].151 - 153 see Il. 24.770; Od. 2.47. 234; 5.12).

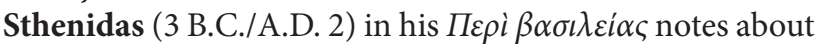

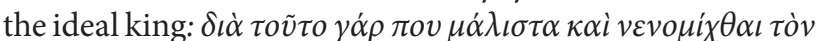
$\pi \rho \tilde{\alpha} \tau o v \theta \varepsilon \dot{v} v \pi \alpha \tau \dot{\varepsilon} \rho \alpha \mu \dot{\varepsilon} v \theta \varepsilon \tilde{\omega} v, \pi \alpha \tau \dot{\varepsilon} \rho \alpha \delta \dot{\varepsilon} \dot{\alpha} v \theta \rho \dot{\omega} \pi \omega v \tilde{\eta} \mu \varepsilon v$,

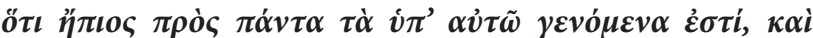

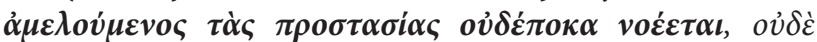

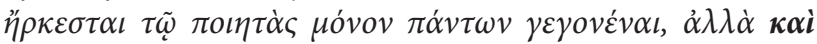

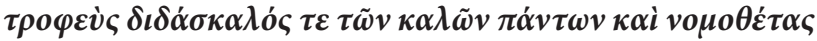
$\pi \dot{\varepsilon} \varphi v \kappa \varepsilon \pi \tilde{\alpha} \sigma \nu v \dot{\varepsilon} \pi i \sigma \alpha \varsigma$ (Stob. 4.7.63) ${ }^{47}$. Ephstathius of Thessaloniki (c. 1115 - 1195/6) notes in his Y $\pi \dot{\mu} \mu \nu \eta \mu \alpha-C o m m e n-$

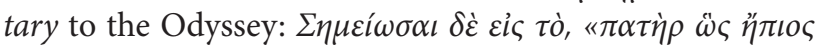

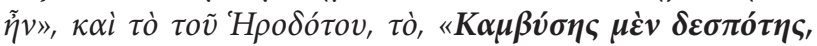

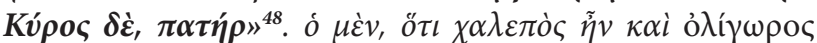

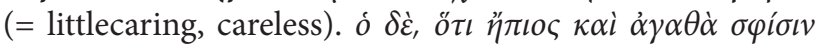

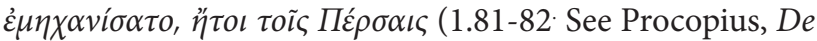

\footnotetext{
3 Chrys Caragounis, Did Paul Behave as an Infant or Imbecile, or as a Gentle Nurse? http://www.chrys-caragounis.com/Studies/Did\%20Paul\%20 Behave.pdf, 17-18.

44 See also Philo, Dec 1:67; Mos. 1:72. Pseudo-Phocylides Gnom.,

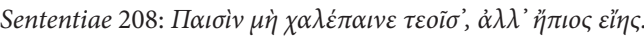

$45 \Pi \lambda \varepsilon o v \varepsilon \xi i \alpha$ in 1 Thes. doesn' $\mathrm{t}$ declare only the gain derived from

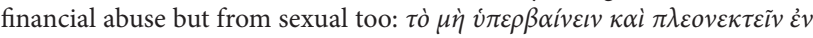

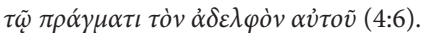

46 'Gentle as a Nurse': The Stoic Background to 1 Thess. II. NovT 12

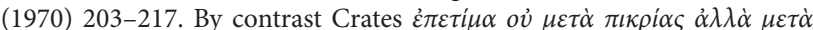

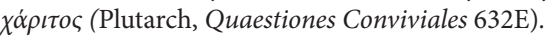

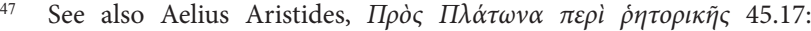

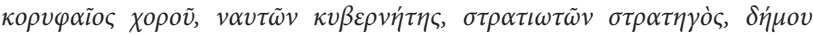

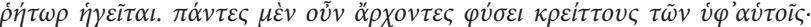

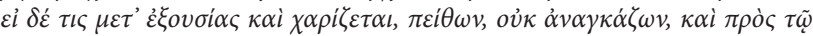

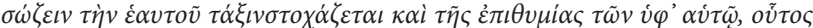

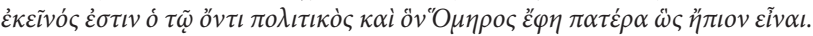
48 Herod. 3.89
}

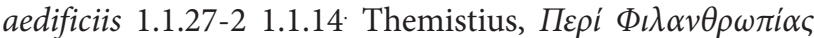
16.a.6-17.a.7).

From the aforementioned quotes we conclude that $\ddot{\eta} \pi \iota \circ \varsigma$ stands not only for having or showing a mild, kind, or tender temperament or character but (as betrays its

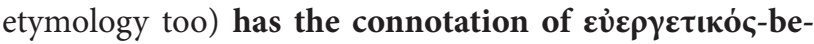

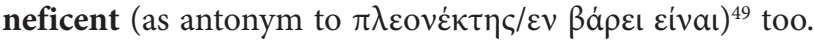
Possibly this phrase of Odyssey, which along with Iliad was the most popular reading in Greco-roman society, had become some kind of motto for the fundamental virtue of the leader: acting like a benevolent and beneficient father.

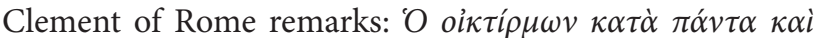

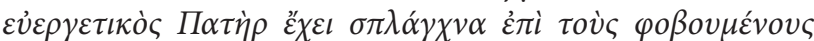

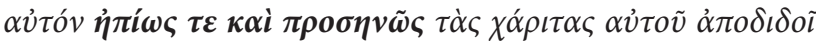

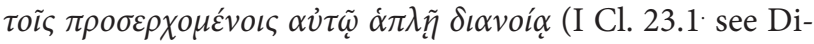
ogn. 7.4).

Paul, the founder and the 'leader' of the Thessalonian church, in his most ancient document does not refer directly to the scriptures (Old Testament) at all but uses familiar to the audience's ears terms drawing upon the greek literature such as $\theta \dot{\alpha} \lambda \pi \omega$ or $\sigma \tau \dot{\tau} \dot{\gamma} \omega \omega$ (3:1.5) or $\sigma \alpha \dot{v} v \varepsilon \sigma \theta \alpha l$ (3:3). Having knowledge of the aforementioned motto, he uses it because it also corresponds to the distinctive Old Testament virtue of the Sheppard, $\pi \rho \boldsymbol{\alpha o} \tau \boldsymbol{\tau} \tau \boldsymbol{\alpha}^{50}$. This virtue (meekness-

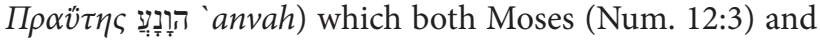
David (Ps. 131:1 Lxx) possessed, doesn't only signify courteousness in manners but also humility and charity. Jesus himself fulfilled Zechariah's prophecy (9:9; Mt.21:5; John 12:15) about the entrance of the meek king to Jerusalem and blessed the meek as well ${ }^{51}$. In the Lxx the term meek stands for the Jewish term Anawim which defines the poor people of God that many Jewish sects had as model ${ }^{52}$.

Obviously, Paul associates himself to the Lord as a father figure and feels that he embodies the virtue of $\pi \rho \alpha \tilde{v} \tau \eta \varsigma$ which however 'translates' for his greek audience with the word $\ddot{\eta} \pi$ เoc. Yet in this context he portraits himself as a nurse, not as a father because he wants to present by a unique way in the ancient literature his extreme love and care in contrast to those who use flattering speech or had greedy motives or seek glory from people. Instead of using the above motto $\pi \alpha \tau \dot{\eta} \rho \tilde{\omega} \boldsymbol{\varphi} \ddot{\eta} \pi \iota s \tilde{\eta} \varepsilon \boldsymbol{v}$-a gentle father he was,

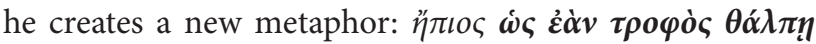
$\tau \grave{\alpha} \dot{\varepsilon} \alpha v \tau \tilde{\eta} \varsigma \tau \boldsymbol{\varepsilon} \kappa v \alpha$ - just as a nursing mother cherishes her own children. He surpasses Mosses who says: $\mu \grave{\dot{\varepsilon}} \gamma \dot{\omega} \dot{\varepsilon} v$

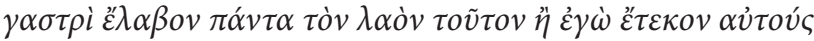

\footnotetext{
49 See also Jos. Ap 1:186. Philo, Sac. 1:27.According to Dio, Or. 32, 10.5-9

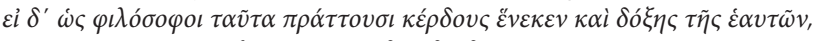

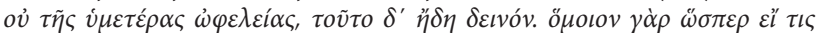

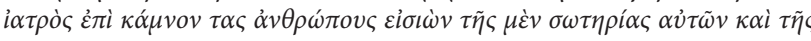

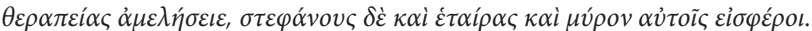
50 In Esther the two terms interchange: $\dot{\varepsilon} \beta o v \lambda \dot{\eta} \theta \eta v \mu \grave{\eta} \tau \tilde{\omega} \theta \rho \alpha \dot{\sigma} \sigma \varepsilon l \tau \tilde{\eta} \varsigma$

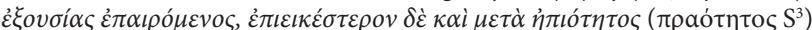

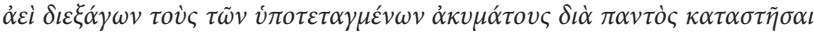

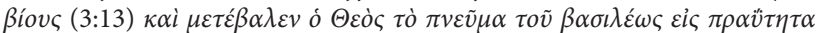

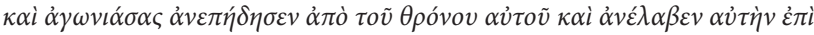
$\tau \dot{\alpha} \varsigma \dot{\alpha} \gamma \kappa \alpha ́ \lambda \alpha \varsigma \alpha \dot{v} \tau o \tilde{v}$ (5: $1 \mathrm{Lxx})$.

51 "Blessed are the meek, for they shall inherit the earth. (Matt. 5: 5 Psalm 36 [37]: 11). See also Matt. 11: 29-30.

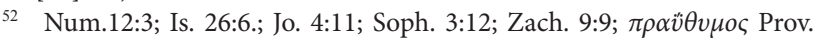

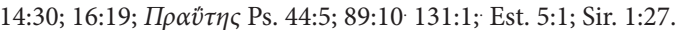




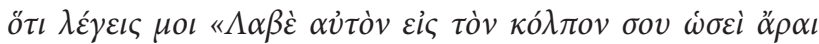

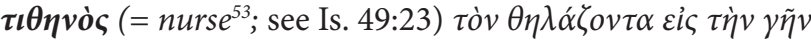

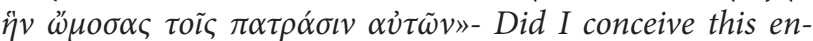
tire people? Did I give birth to them, that you should say to me, 'Carry them in your bosom, as a nurse carries a sucking child, to the land that you promised on oath to their ancestors?' (Num. 11:1254). At the same time he imitates God, who in Isaiah 49:14-16 (a chapter that has deeply affected Paul's psychology Gal. 1:15) presents himself as a nursing woman who doesn't forget her child and saves Israel with her compassion.

What is strange is the fact that Paul feels nursing love not for the chosen people of Israel (who accuses with hard words in the next paragraph) but for the Gentiles who now populate the Church and are carried by the Apostle to the

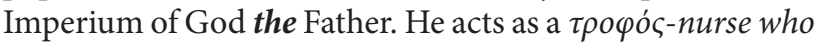
$\theta \dot{\alpha} \lambda \pi \varepsilon$ - cares especially for her own children ${ }^{55}$. I believe that he uses the word $\tau \rho o \varphi o^{56}{ }^{56}$ and not $\mu \eta \tau \dot{\varepsilon} \rho \alpha^{57}$ because the emphasis in this context is not on the birth ${ }^{58}$ but on the Gospel

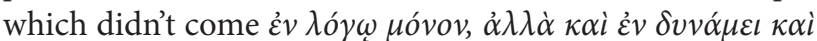

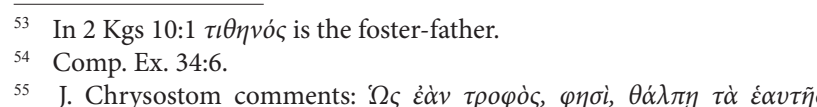

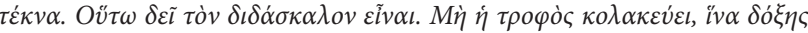

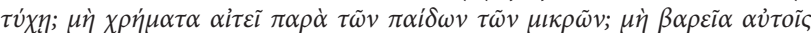

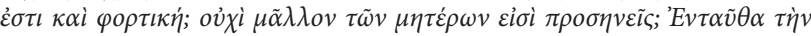

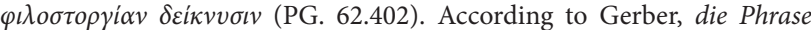

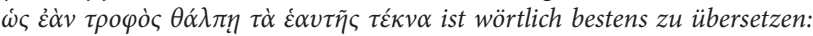
"wie eine Amme ihre leiblichen Kinder hegt". Der Absender vergleicht sich mit einer Amme, die sich als Mutter um ihre leiblichen Kinder kümmert ohne dafür Geld zunehmen. Die argumentative Valenz des Vergleichs liegt darin, den Unterhaltsverzicht der Missionare bei ihrem Aufenthalt in Thessalonica durchsichtig zu machen auf die sich in ihm ausdrückende "mütterliche" Hingabe an die Gemeinde (Paulus und seine ,Kinder" 277).

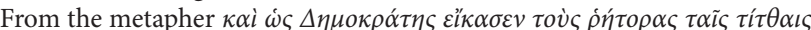

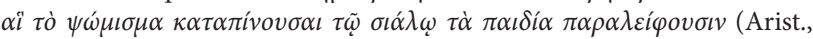
Rhet. 1407a.8-10) but also from the urging of the Pseudo-Plutarch to the mothers to feed themselves their own babies (see next footnote), we conclude that the main characteristic of the behavior of the nurse to the 'other' children was that they showed i

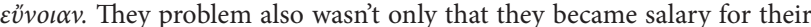
services, but didn't show real love, which in contrast is the characteristic of

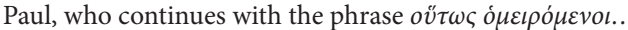

56 From the Patristic Lexicon of Lambe results that not only the rabbis but also the church Fathers avoid to characterize themselves as трофóc.

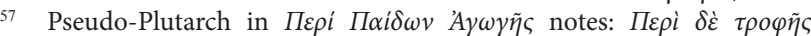

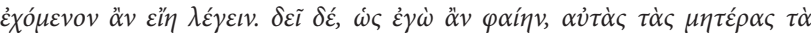

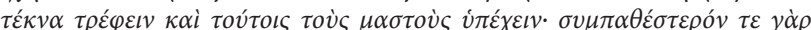

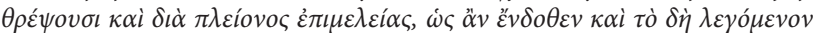

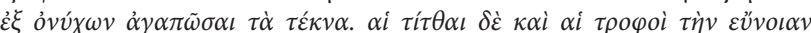

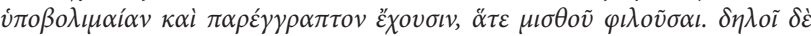

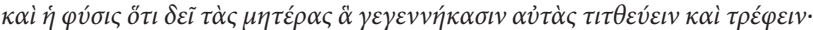

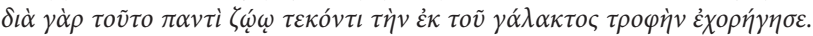

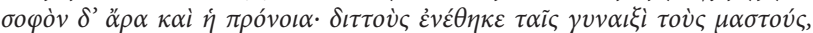

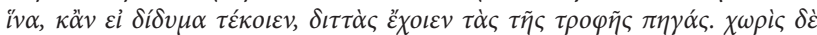

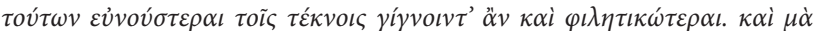

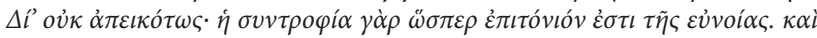

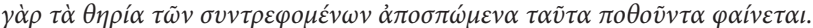

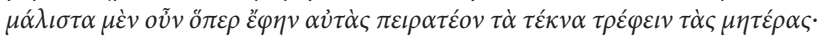

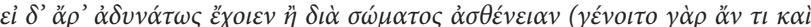

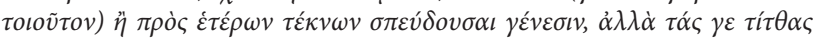

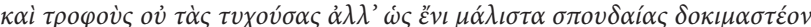

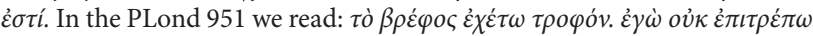

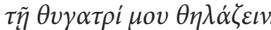

${ }_{58}$ Paul as father/mother isn't contrasted with other instructors in Christ as in 1Co 4:15; Gal. 4:19.

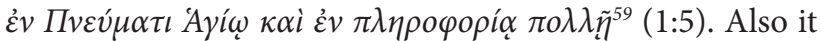
functioned as $\eta \tau \rho \circ \varphi \eta^{60}$ - the milk to the newborn. With $\theta \dot{\alpha} \lambda \pi \omega$ (which originally means to heat) ${ }^{61}$ possibly is implied the transmission especially of the Holy Spirit which in 5:19 is pictured as fire ${ }^{62}$. At the same time just like a mother he longs his own children and can't bear being apart from them: So being affectionately desirous of you, we will to impart unto you, not the gospel of God only, but also our own souls, because you were dear unto us $(2: 8)$. In the direct

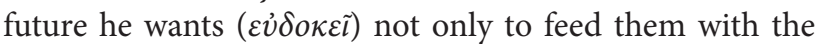
Gospel but also to offer his psyche/existence ${ }^{63}$ which is a characteristic particularly of the mother as Plutarch proves

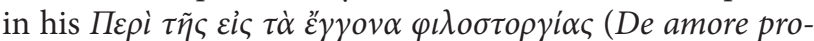
lis $)^{64}$. In this sense he differentiates himself absolutely from the itinerant philosophers and functions $\kappa \alpha \tau^{\prime}$ Eıkóv $\alpha$ of his Lord who died for us $(5: 10)^{65}$.

Based on what has been said, we interpret 2:7b-8

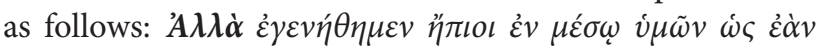

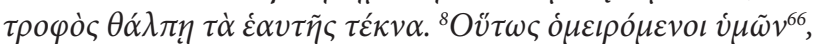

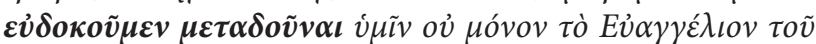

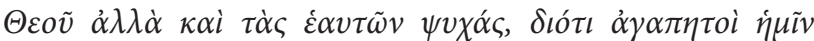
$\dot{\varepsilon} \gamma \varepsilon v \dot{\eta} \theta \eta \tau \varepsilon^{67}$. - But we were gentle and beneficent among you, like a nurse tenderly caring for her own children. So deeply do we care for you that we are determined to offer to you not only the gospel of God but also our own selves, because you have become very dear to us.

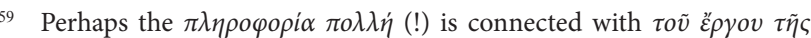

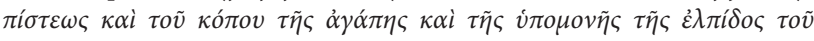

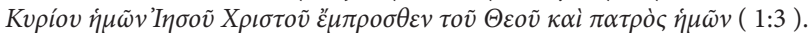

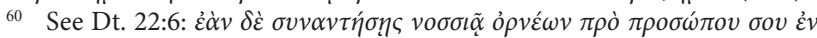

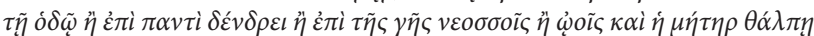

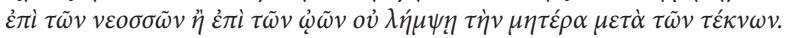

${ }_{61}$ About the modern translation of this verb in 2:7c see Gerber, Paulus und seine 'Kinder' 285 Anm. 142. See also her critic to K.P. Dornfried (The Cults of Thessalonica and the Thessalonian Correspondence, NTS 31 (1985) 336-356) who relates this verse with the cult of Dionysos and the
\end{abstract} Nyphs who functioned as nurses (p. 293).

${ }_{62} \theta a \dot{\lambda} \lambda \pi \omega=$ to be or become warm (so it is used by Philo), to hatch, to cherish, comfort, consulate (Eph 5:29). According to Babiniotis, $\Lambda \varepsilon \xi ı$ ı́ 740

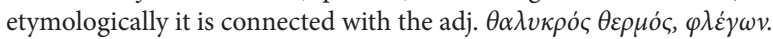

${ }^{63}$ The $\delta \iota \delta o ́ v \alpha \iota \tau \dot{\eta} v \psi v v \chi \dot{\eta} v$ is used in Sir.7:20 for the service of the slaves. See also Jos., Ant. 2.144 (to sustain our lives by grain).

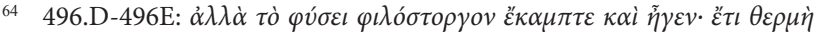

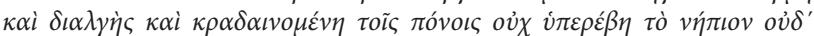

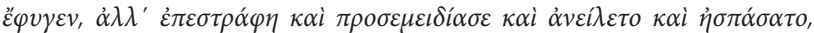

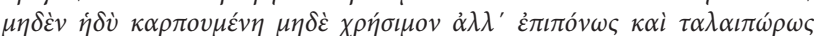

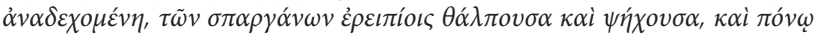

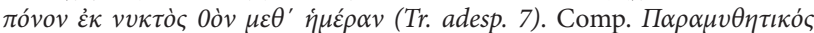

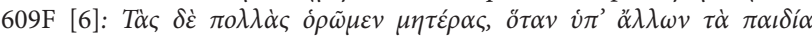

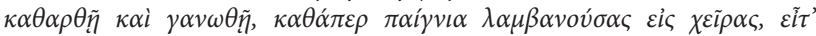

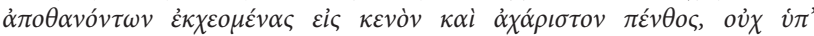

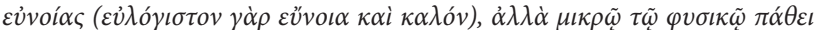

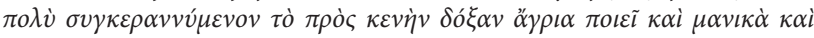
$\delta v \sigma \varepsilon \xi \hat{\varepsilon} \lambda \alpha \sigma \tau \alpha<\tau \dot{\alpha}>\pi \dot{\varepsilon} v \theta \eta$.

${ }^{65}$ It comes as a surprise that even at this point he does not refer to the Cross at all, the climax of sacrificing love. Is it possible because it was an abomination for the enemies of the Thessalonians' Church? Did he hesitate to link faith to scandal in his first epistle? It is well known that in the future he will emphasize the significance of the Cross, mocking human wisdom and logic with it.

${ }_{66}$ For ó $\mu \varepsilon ı \rho ́ \mu \varepsilon v o l$ ("ardently desiring") a number of minuscules read the classical i $\mu \varepsilon \imath \rho$ ó $\mu \varepsilon v o l$, which has ths same meaning. See Ps. 62:2 (Symm.) Job 3:21 (Lxx).

67 Ч. Byz.: $\gamma \varepsilon \gamma \varepsilon \dot{\varepsilon} \vee \eta \sigma \theta \varepsilon$. 
The following two things are impressive: a) while past tenses dominate in this context, here the present

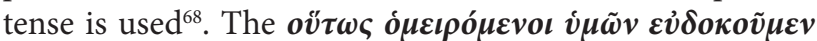

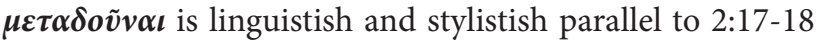
which prefaces the second subunit (2:14-3:13) and describes the efforts of Paul personally (2:18: $\boldsymbol{\varepsilon} \gamma \dot{\boldsymbol{\omega}} \delta$ П $\Pi \alpha \tilde{v} \lambda \circ \varsigma)$ to bridge the local gab between him and his audience from the past to the present, expressing the wish to meet face to face with them in Thessaloniki in the near future:

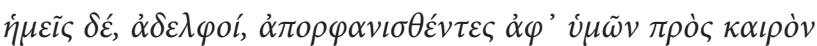

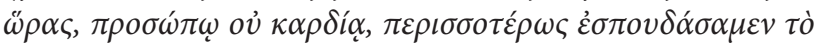

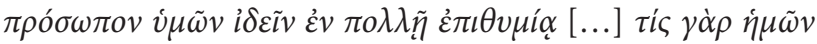

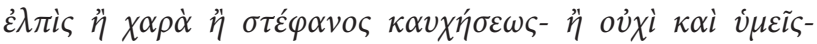

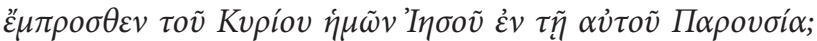

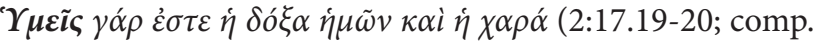
Phil. 4:1 ${ }^{69}$. J. Chrysostom, who has studied rhetoric by Libanius, doesn't hesitate to characterize the language of Paul

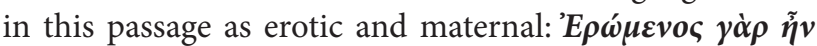

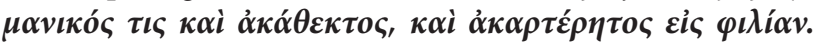

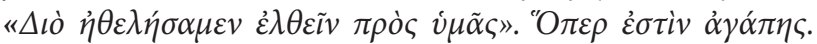

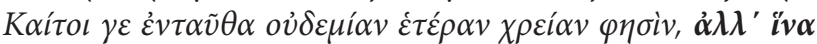

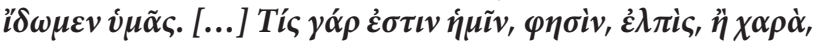

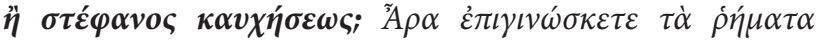

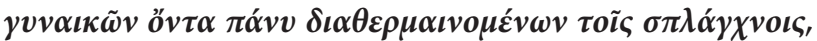

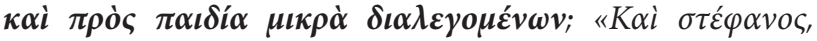

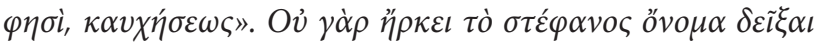

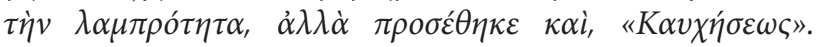

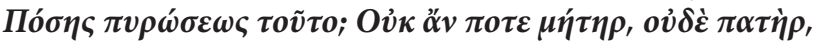

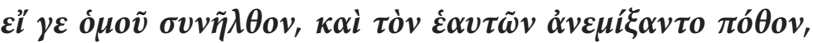

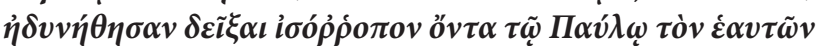
$\pi \hat{\theta} \theta \boldsymbol{o v}$ (PG. 62.409). That means that the expression of the maternal feelings of Paul isn't limited in v. 7b-8 but it is extended in v. $17-18^{70}$.

b) The reason why Paul desires to impart his life to the Thessalonians is not because he has begotten them through the gospel (1 Kor. 4:13) but because they have become very dear to the apostles. Using you have become, he turns back to the most crucial moment in the past and stresses their (the Thessalonian's) contribution to his abundant sacrificing love. The beloved children of God became Paul's dear children, apparently by the way they responded to his preaching.

Finally in v. 10-12, where the ethos of the apostles is positively portrayed (that is without the negative pronouns of 2:3), Paul presents himself not as a mother who is responsible particularly for the first years of the human existence but as a father ${ }^{71}$ who undertakes according to Plutarch's De

\footnotetext{
68 In some manuscripts the tense is "corrected", that is turned back to past tense.

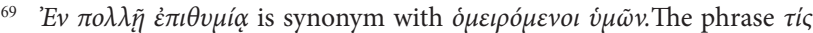

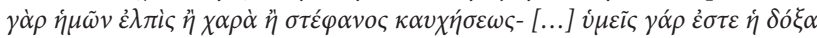

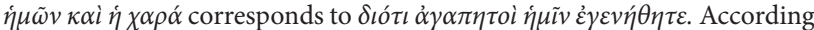

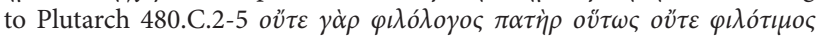

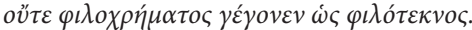

70 About the modern exegetes who consider that the Parents-Children metaphor continues in 2:17-20 see Gerber, Paulus und seine 'Kinder' 314 Anm. 287

${ }^{71}$ He has already done so by stating himself as an example to them in 1:6.
}

amore prolis the $\alpha \dot{\alpha} \alpha \tau \rho \circ \varphi \eta^{\prime}$ (= upbriging) ${ }^{72}$ : You are witnesses, and God also, how devoutly (referring to faith in God) and justly (referring to the relationship with other people) and blamelessly (refers to the way they conducted) we behaved ourselves among you who believe; ${ }^{11}$ as you know how we (i) exhorted, and (ii) comforted, and (iii) charged every

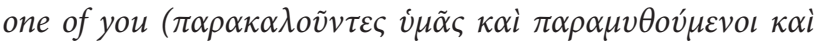
$\mu \alpha \rho \tau v \rho o ́ \mu \varepsilon v o l)$, as a father does his own children, ${ }^{12}$ that you would walk worthy of God who calls you into His own kingdom and glory ${ }^{73}$. According to Gerber the ethical exhortation of the children was a Jewish custom par excellence ${ }^{74}$. I believe that the instruction was as well a custom for the Greek low classes (to which belong the recipients of the epistle) who didn't have the financial opportunity (the tyche according

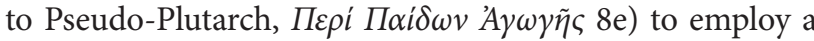
paidagogos. According to Burke in this verse Paul is employing a metaphor of unambiguous superiority ${ }^{75}$. The meaning however of a metaphor is also given from the context: Paul focuses here on his personal relationship with each one of his receivers while he emphasizes that his exhortation and encouragement didn't aim to his own glory but that is worthy of God's call to His Kingdom-Imperium and His Kabod/ Glory $^{76}$. The verb $\pi \alpha \rho \alpha \kappa \alpha \lambda o \tilde{v} v \tau \varepsilon \varsigma \hat{v} \mu \tilde{\alpha} \varsigma$ in combination with

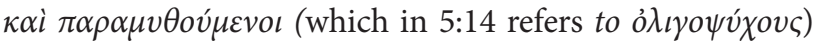
${ }^{77}$, which are used also in the paraenetic section of 1Thes. ${ }^{78}$ (and by this verse the audience is prepared for this), don't declare the superiority (as it happens with $\pi \alpha \rho a \gamma \gamma \dot{\varepsilon} \lambda o \mu \varepsilon v 2$ Thes. 3:6) but according to Chrysostom the ä $\tau v \varphi o v$ of the apostle ${ }^{79}$ and his love and his care for people who need con-

\footnotetext{
72 See Gerber, Paulus und seine, Kinder' 307.

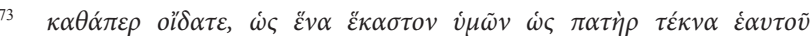

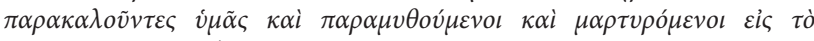

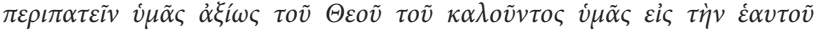
$\beta \alpha \sigma \iota \lambda \varepsilon i \alpha v \kappa \alpha i ̀ \delta o ́ \xi \alpha v$

74 Paulus und seine 'Kinder' 304.

75 A Socio-Historical Study of Kinship Metaphors in 1 Thessalonians 67.

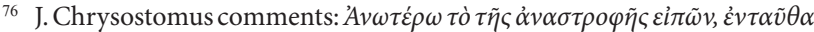

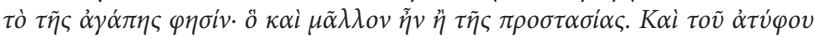

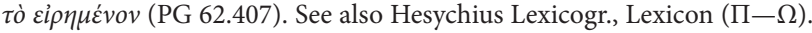
(A.D. 5/6) (894.) $\pi \alpha \rho \eta \gamma$ о $\rho \varepsilon \tilde{\imath} \cdot \pi \alpha \rho \alpha \kappa \alpha \lambda \varepsilon \tilde{\imath}$, $\pi \alpha \rho \alpha \mu \nu \theta \varepsilon \tilde{\varepsilon}(\tau \alpha \iota)$. Lexicon

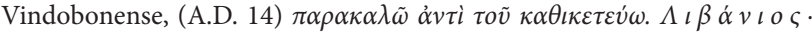

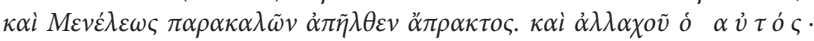

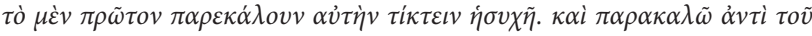

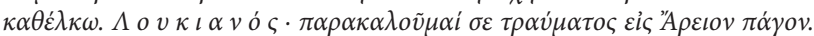

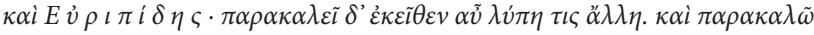
$\tau \dot{~} \pi \alpha \rho \alpha \mu v \theta o \tilde{v} \mu \alpha \iota$.

77 Together with $\mu \alpha \rho \tau v \rho o ́ \mu \varepsilon v o$ เ they build a climactic trias. M $\alpha \rho \tau v \rho o ́ \mu \varepsilon v o l$ is used to underline the fact that the Kerygma which rescues us from the coming wrath is not a simple consolation but it has the characteristics of

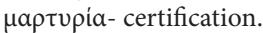

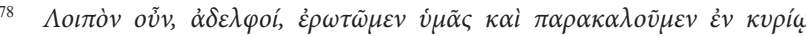
'I

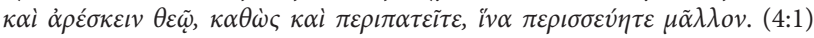
${ }^{4} \Pi \alpha \rho \alpha \kappa \alpha \lambda o \tilde{v} \mu \varepsilon v \delta \dot{\varepsilon} \dot{v} \mu \tilde{\alpha} \varsigma, \dot{\alpha} \delta \varepsilon \lambda \varphi o i ́, v o v \theta \varepsilon \tau \varepsilon \varepsilon \tau \tau \varepsilon \tau o \dot{c} \varsigma \dot{\alpha} \tau \alpha \dot{\alpha} \kappa \tau o v \varsigma, \pi \alpha \rho \alpha \mu v \theta \varepsilon \tilde{\imath} \sigma \theta \varepsilon$

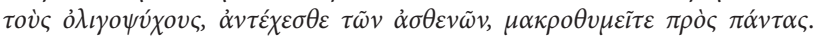
(5:14). See the comments of the Fathers to this verse: 'Ev $\tau \alpha \tilde{v} \theta \alpha \pi \rho \dot{o} \varsigma \tau o \dot{v} \varsigma$

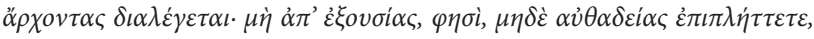

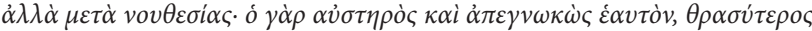

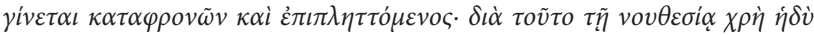

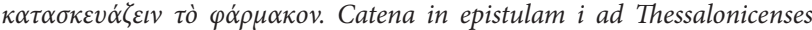
(typus Parisinus) (e cod. Coislin. 204).

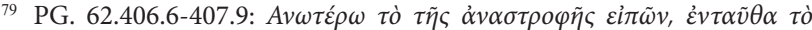

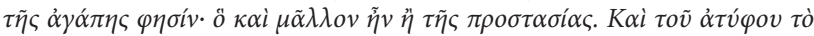

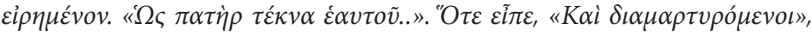




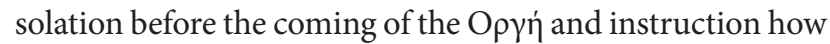
they must $\pi \varepsilon \rho \iota \pi \alpha \tau \varepsilon \tilde{v}$ and $\dot{\alpha} y i \dot{\alpha} \zeta \varepsilon \varepsilon v$ themselves so as to be eternally with Kyrios in his own Kingdom (5:14). We have also seen that the maternal element dominates in the the periscopes which frame this vers.

It is clear that in the passage of 1 Thes. dominant is the authority of God while in the second the one of the sender. Paul's word in 1Thes. 2 was not accepted because the receivers have recognized in the word of Paul the logos of God who in the passage 2:1-13 is mentioned 12 times!: Kai $\delta i \dot{\alpha}$

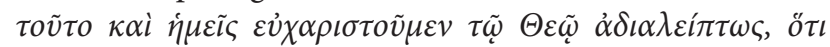

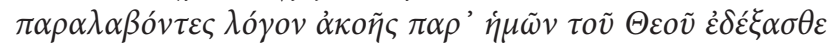

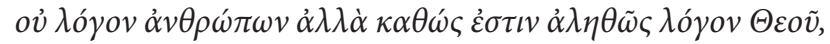

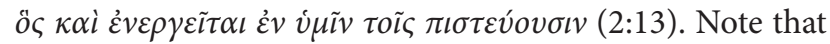
at the beginning of the exhortation the apostle will remark:

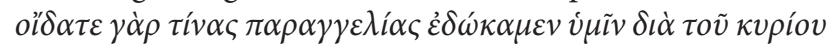

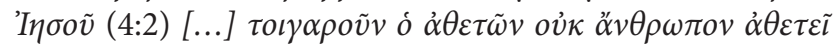

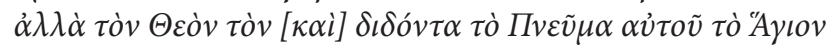
Eic $\dot{v} \mu \tilde{\alpha} \varsigma(4: 8) .{ }^{80}$

We conclude that the image of the mother/nurse and her beneficency-love (which stand in the core of the chiasmus in 2:1-12 but also in the prologue of the section 2:133:13) is called upon to show that Paul and his own assistants constantly yearn to impart the Thessalonians their own lives (and not only verbal admonitions), while the image of the father is used especially for the personal teaching in the past and comforting facing the Parousia of Jesus. Both express the opposite of seeking glory and profit and simultaneously the unique ethos of Paul and his Paraclese which aims at being sanctified entirely; and may your spirit and soul and body be preserved complete, without blame at the coming of our Lord Jesus Christ (5:23).

\section{Paul's intimacy with the audience in Context}

Here we will show how Paul presents himself as father in 1 Thess. context: A. The author does not accompany his

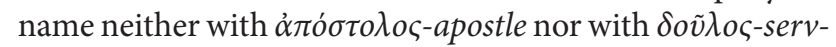
ant. Apparently he wants them to feel comfortable with him (through avoiding the agitation that accompanies heavy duty titles) and his close attendants that accompanied him in his first travel to the West. He experiences the same afflictions with them and in the epilogue he requests for their prayers (5:25). At this point paradoxically are lacking the personal greetings of Paul and his associates.

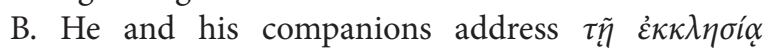

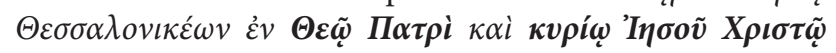

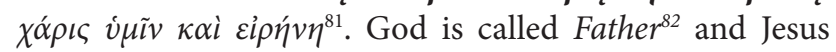

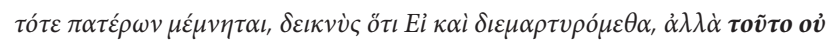
$\sigma \varphi o \delta \rho \tilde{\omega} \varsigma, \dot{\alpha} \lambda \lambda^{\prime} \dot{\omega} \varsigma \pi \alpha \tau \varepsilon \dot{\rho} \rho \varepsilon$.

${ }_{80} \mathrm{He}$ is not referred to as Father while the following imitation does not refer to Paul but the churches in Judea.

${ }_{81}$ In 2:14 he speaks of the churches of God which are in Judea in Christ

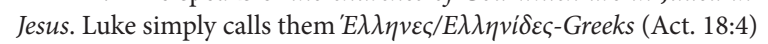

82 According to F. Graf (Zeus DDD 934-936) the Homeric and later
Christ, the Lord perhaps in opposition to Zeus and the

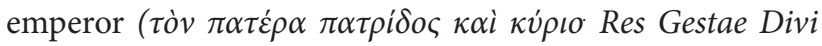
Augusti 37). The living and true God (1:9) is Father par excellence because he has Son who has died for us (5:10) but God has raised him from the dead (1:10). As it is underlined in the Praise which introduces and concludes the first part of the epistle (1:3; 3:13), God is Father of all the Christians $(\dot{\eta} \mu \tilde{\omega} v)$ so as Jesus is the Lord of us, because of the election $^{83}$. Furthermore he has a special relationship with Paul and the other apostles of Jesus Christ (3:11) who are

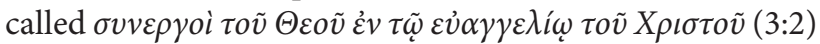
since they have been approved and are tested $(2: 8)^{84}$. This God will rescue us who await patiently His Second Coming from the coming wrath (1:10). All the believers, the beloved of this Father, who have been orphans away from their compatriots and their families (2:14-17), although they are likely coming from the lower classes of the society, constitute the Ecclesia of the Thessalonians (1:1) with a different $\pi o \lambda i \tau \varepsilon v \mu \alpha$ from the equivalent politico-religious institution in the same city ${ }^{85}$. They are Ecclesia in God the Father and the Lord Jesus Christ which (phrase) Paul does not typical-

epithet pater is closely paralleled by Roman Iu-piter and Indian Dyaus pitar: his role as father must be already IE, not in a theogonical or anthropogonical sense (regardless of the frequent epic formula "Zeus, falher of men and gods"), but as the Homeric variant Zeus anax, "Lord Zeus", proves, as having (he power of a father in a patriarchal system. This role, which implies unrestricted power as well as its control by father-like benignity, continues as the fundamental role of Zeus in all antiquity and finds expression also in the standard iconography of a bearded but powerful man (934). In the biblical tradition in spite of the popularity of the epithet 'Father' in personal names, the epithet is not common in the texts. God can be addressed as 'My/Our Father' (Jer 3:4.19; Isa 63:16; 64:7[8]| and can be characterized as a father/ creator, with Israel as his son/children (Exod 4:22; Deut 14:1; 32:6.18; Hos 2:1 [1:10]; 11:1; Isa 1:2; 45:10-12; Jer 31:9; Mai 1:6; 2:10; cf. Mum 11:12; Ps 68:6[5]). Another illustration is Jeremiah's accusation that some people address a piece of wood with "You are my father", or a bit of stone with "You gave birth to me" (Jer 2:27), using language that should be reserved for God only. In the texts, God is also identified as 'like a father' (Ps 103:13; Prov 3:12), and, in keeping with the parental model, even as a-mother (Isa 42:14; 45:10; 49:15; 66:13), but various other metaphors are more frequently used. As 'father', the emphasis is on God as protective and compassionate, Israel was reluctant to describe God as a physical father, except in an ultimate sense. In particular, God is described as father of the Davidic king (2 Sam 7:14; 1 Chr 28:6; Pss 2:7: 89:27-28(26-27); Isa 9:5[6]), who in turn may have the title 'Eternal Father' (Isa 9:5(6]). The emphasis, however, is on sonship via adoption: "This day have I given birth to you" (Ps 2:7). [...] In the NT the conception remains basically the same, but with well over 200 occurrencesmore than 120 in the Johannine corpus alone-the epithet 'Falher' virtually explodes in popularity. While remaining primarily an epithet, 'Father' is also used in direct address to God. The use of this title in the Aramaic-speaking circles of the early Christian community is retained in the double invocation "Abba. Father" in a Gethsemane prayer by Jesus (Mark 14:36) and in the Spirit cry, cited by Paul (Rom 8:15; Gal 4:6).See H.B. Huffmon, Father, DDD 236-238.

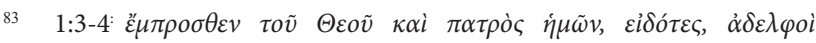

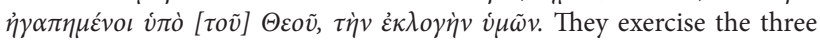
virtues (faith, love, hope) with work, labor and patience (1: 3). Of course given that Paul refers to what is lacking in their faith $(3: 10)$ while he devotes a whole section of the epistle's exhortating part to brotherly love (4: 9.10), one might say that what is said in 1 Thess.1:3 is used within a captatio benevolaentiae framework.

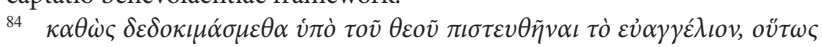

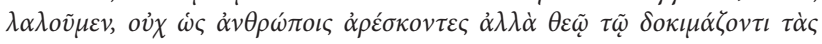
$\kappa \alpha \rho \delta i \alpha \varsigma \dot{\eta} \mu \tilde{\omega} v(2: 4)$

85 They aren't a voluntary association (a thiasos of one God or a collegiums) with cultic, professional or funeral purposes. 
ly use for the opening of an epistle ${ }^{86}$. This (in...) could be linked to the church (1:1b) but also to Grace to you $^{87}$ and peace-shalom $^{88}$. The Christians of Thessaloniki (who are not called in this epistle saints) constitute a Church, like the Hebrew Qahal and the Greek Ecclesia, because of the

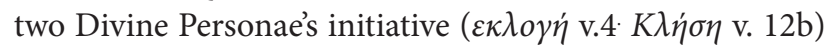
to offer Grace (forgiveness of sins-amnestie) and Peace, one of different quality from that of Pax Romana whose peace is fragile and susceptible to an end as he proclaims in 5:1. 'Ev-in could not only mean the medium, but also the place where the Church is existing and functioning as an entity-a family (comp. 2:14), especially since Paul already experiences being in the presence of God through prayer $(1: 3 ; 3: 9)$. Through the final coming of Jesus and the raising of the dead, all Christian will be always ov̀v Kvpí $\omega$

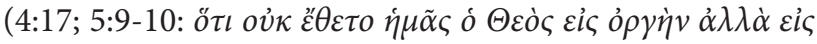

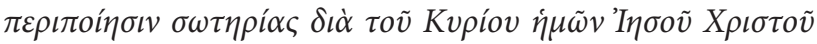

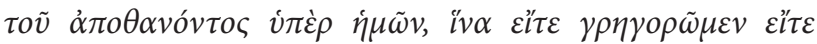
$\kappa \alpha \theta \varepsilon \dot{\delta} \delta \omega \mu \varepsilon v \ddot{\alpha} \mu \boldsymbol{\alpha} \sigma \dot{v} v \boldsymbol{\alpha} \dot{v} \tau \tilde{\omega} \zeta \bar{\eta} \boldsymbol{\sigma} \omega \mu \varepsilon v)$. For this reason we

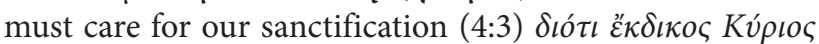
(4:6).

C. At the introductory Praise, the part that responds to Grace and covers three chapters ${ }^{89}$, the words always and without ceasing about the Eucharist (thanksgiving) refer to all the holy brethren in the church ${ }^{90}$ and this is emphasized in the epilogue too: Greet all the brethren with a holy kiss. I charge you by the Lord that this epistle be read to all the holy brethren $n^{91}$ (5:27). What is also obvious is Paul's aim to maintain the feeling of connection between $\dot{\eta} \mu \varepsilon \tilde{\varepsilon} \varsigma$-we and all the $\dot{v} \mu \varepsilon \tilde{\varepsilon} \zeta-y o u$ by and large. For now this connection is accomplished through the mention in prayer, the Thessalonians and their work of faith, labor of love, and patience of hope $(1: 2.3)^{92}$.

D. In this frame, Paul, who in v. 2:18 through $\dot{\varepsilon} \gamma \omega$ dis-

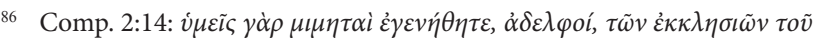

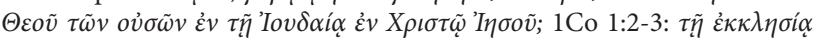

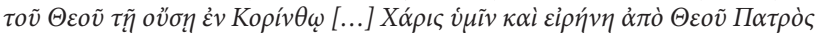

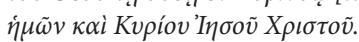

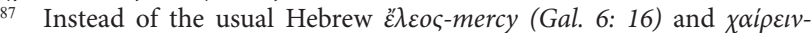
Greetings (James 1: 1). The two last elements (grace and peace) are usually found in other epistles as coming from God our Father and the Lord Jesus

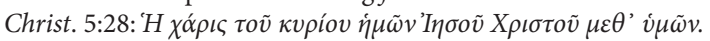

${ }_{88}$ The same problem does exist in 1 Thes. with $\kappa \alpha \theta \dot{\omega} \varsigma$ ol $\delta \alpha \tau \varepsilon$ oĩo $\dot{\varepsilon} \gamma \varepsilon v \dot{\varepsilon} \theta \eta \mu \varepsilon v[\dot{\varepsilon} v] \dot{v} \mu \tilde{i} v \dot{l}^{\prime} \dot{v} \mu \tilde{\alpha} \varsigma(1: 5 \mathrm{c})$ which can be read with the previous but also the following vers.According to Aristoteles $\delta ̋ \omega \varsigma \delta \dot{\varepsilon}$

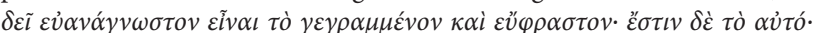

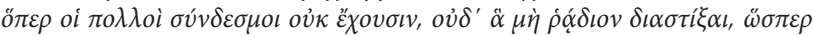

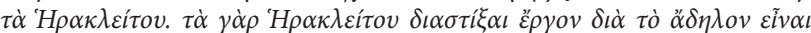

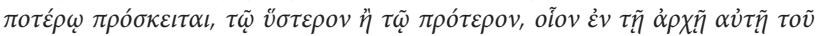

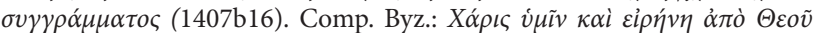

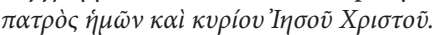

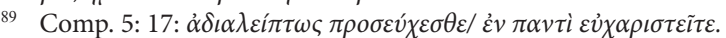

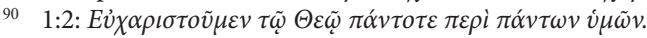

91 Reidar Aasgaard, 'My Beloved Brothers and Sisters'. Christian Siblingship in Paul. T\&T Clark International. London-New York 2004. Ph. Harland, Familial Dimensions of Group Identity: 'Brothers' (A $\Delta \mathrm{E} \Lambda \Phi \mathrm{OI})$ in Associations of the Greek East, Journal of Biblical Literature 124 (2005) 491-513. -"Familial Dimensions of Group Identity (II): 'Mothers' and 'Fathers' in Associations and Synagogues of the Greek World," Journal for the Study of Judaism in the Persian, Hellenistic, and Roman Period 38 (2007) 57-79. http://www.philipharland.com/publications.html.

92 At closure he will ask of them: Brethren, pray for us (5:25).
}

tinguishes himself from his associates, devotes the second half of the first part of his epistle to underline his attempts from the past to present to maintain personal - bodily communion with the Thessalonians. Satan ${ }^{93}$ however blocked

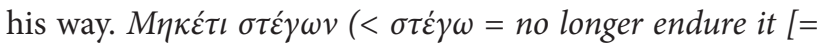
the fact that he had not communion with the Thess. $]^{94}$ ) as he states twice, he did not hesitate to be left alone, sending his brother, Timothy ${ }^{95}$. Paul considers the return of Timothy who brings news of the faith and love of the Thessalonians as well as the fact that they remember and long to see him, as a Gospel: But now that Timothy has now come to us from you, and brought us good news of your i) faith and ii) love, and that iii) you always have good remembrance of us, greatly desiring to see us, as we also to see you (3:6). These good news that Timothy brings soothes Paul and gives him life. At the end of the first part of his epistle, Paul continues to wish: now may our God and Father himself and our Lord Jesus direct our way to you (3:11) so that three goals may be accomplished: a) restoring whatever is lacking in their faith, b) the increase and abound in love for one another and for all c) the establishing of their hearts blameless in holiness before our God and Father at the coming of our Lord Jesus with all his saints (3: 12.13). Given what is said apart from the faith in God it is also the faith-trust (fides) in Paul that is being verified because, among others, his prophecies are fulfilled.

E. In the second part of the Epistle (ch. 4-5) it is clear that Paul wants to differentiate the Church (whose members are the sons of light and sons of the day-5:4.5) through its ethos-ethic from the others who have no hope (4:13) and those who sleep and get drunk at night (5: 6.7). They are the 'E $\theta v \eta$ who do not know God and live with lustful passion (4:5), destined for wrath and not to obtain salvation through our Lord Jesus Christ (5:9). All church members are brothers who make up a family-community that is different from the Gentile Ecclesia which worships Caesar as Lord and Father of the empire and the world. The Church of Jesus Christ is brought together through i) recognition (for) those who labor among you, and are over you in the Lord and admonish you, ii) be(ing) at peace among yourselves, warn(ing) those who are unruly, comfort(ing) the fainthearted, uphold(ing) the weak and iii) be(ing) patient with all (5:12-14). This Koinonia will be perfected in the future, for we will always be with the Lord.

It is clear of the aforementioned that particularly in the first section of his oldest epistle, Paul underlines the vertical communion of the audience, their relationship with the Living/True God who is Father to his Son who died for us (5: 10) and was resurrected from the dead. He comes back and save us from the coming wrath. Yet the Father is a father to us all. In fact he calls them beloved by God and brothers. That is very important for an audience which had been ostracized from their family and social circle because of their faith in Jesus. Apart from having a new Fa-

\footnotetext{
93 Satan seems to act as a dividing agent in general, not only in Paul's case. $94 \sigma \tau \varepsilon \dot{\gamma} \omega=1$. < (s)teg- cover, pass over in silence (1 Cor 13:7), 2. bear, stand, endure (1 Cor 9:12; perh. 13:7).

$95 \quad 3: 2-3$.
} 
ther they have a new Lord, not Caesar but Jesus Christ who was also persecuted and died for us. It is His Coming that will change-save the world and that is the Christian hope. Meanwhile he tries to strengthen the horizontal bond between him and his audience because, as the epilogical vers 3:12-13 indicates, this love functions as model in the relations of the members of the Church and as the main factor

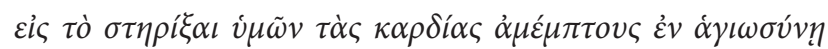

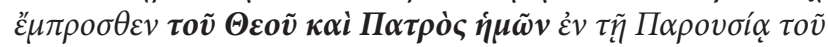

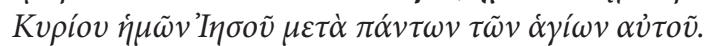

\section{The reasons for the Paul's intimacy}

In his next letters to the Churches, where he faces enemies inside the Ecclesia, Paul will demonstrate himself particularly as pater familiae. The example of 1 Cor. where Paul tells that he fed the Corinthians with milk and not with solid food as to carnal, as to babes in Christ (3:14) is quite distinctive. At the end of the epistle's first part (ch. 1-4), Paul separates himself from the instructors in Christ and instead projects the image of the father (also as an invitation for imitation) threatening them with the rod. In this context Timothy is also mentioned and is presented as beloved (the Corinthians too) and faithful: ${ }^{14}$ I do not write these things to shame you, but as my beloved children I warn you. ${ }^{15}$ For though you might have ten thousand instructors in Christ, yet you do not have many fathers; for in Christ Jesus I have begotten you through the gospel. ${ }^{16}$ Therefore I urge you, to imitate me. ${ }^{17}$ For this reason I have sent Timothy to you, who is my beloved and faithful son in the Lord, who will remind you of my ways in Christ, as I teach everywhere in every church. ${ }^{18}$ Now some are puffed up, as though I were not coming to you. ${ }^{19}$ But I will come to you shortly, if the Lord wills, and I will know, not the word of those who are puffed up, but the power. ${ }^{20}$ For the kingdom of God is not in word but in power. ${ }^{21}$ What do you want? Shall I come to you with a rod, or in love and a spirit of gentleness? (1 Cor. 4:10-21).

In the Epistle to Galatians, which is according to Dunn $^{96}$ also written from Corinth during his first visit, Paul uses the strong language of the advising father. Only after he forcefully accuses them as fools for falling prey to Judeo-Christian false brothers, he says: My little children, for whom I am again in the pain of childbirth until Christ is formed in you, 20 I wish I were present with you now and could change my tone, for I am perplexed about you $\left(\right.$ Gal 4:18-20) ${ }^{97}$.

\footnotetext{
96 J.D.G. Dunn, Beginnings from Jerusalem, Michigan: Eedermans 2009, 720.

97 According to Joh. Chrysostomus (Comm. Titum) the ethos of Paul in

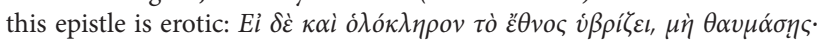

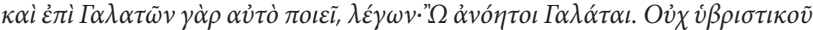
$\delta \dot{\varepsilon} \tau o \tilde{v} \tau o ~ \ddot{\eta} \theta o v \varsigma, \dot{\alpha} \lambda \lambda^{\prime} \dot{\varepsilon} \rho \omega \tau \iota k o \tilde{v}$. (PG. 62.664). About the criterion of

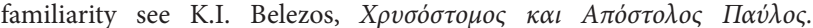

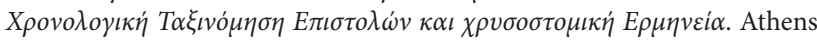
2008, 38. 130-131.
}

While in every other epistle Paul presents himself as pater familias, it is in 1 Thess. that a loving mother ready to share her life and yearning for contact in person is being projected. We have seen that the fact that motherly love surpasses fatherly harshness can be verified through viewing 1 Thess. and 2 Thess. in parallel since in the later Paul acts rather fatherly dealing with problems inside of the Church.

Motherly elements are being shown in his private letter to Philemon. Self-presented as aged (since he was probably near his life's end) Paul writes a warmhearted letter to Philemon for he believes that Onesimus has become a child of his during his imprisonment: yet for love's sake I rather appeal to you-being such a one as Paul, the aged, and now also a prisoner of Jesus Christ- ${ }^{10}$ I appeal to you for my son Onesimus, whom I have begotten while in my chains, ${ }^{11}$ who once was unprofitable to you, but now is profitable to you and to me ${ }^{12}$ I am sending him back. You therefore receive him, that is, my own heart, ${ }^{13}$ whom I wished to keep with me, that on your behalf he might minister to me in my chains for the gospel.

Why Paul shows such intimacy in the 1 Thes.? From what has been said and from the Data of the Acts (despite the fact that the book was written about 30 years later), we draw the following conclusions:

1. The book of Acts shows that during his stay in the city of Athens (17:18-33) Paul felt strongly the hands of loneliness upon him and the disappointment of the rejection of the Stoics and the Epicourians although he had adjusted his word and his strategy to the city's mental climate. When he arrived in Corinth he confessed that he came in weakness, in fear, and in much trembling (1 Cor.2:3). Luke marks that Paul was filled by the Spirit by the return of his associates from Thessaloniki: After Silas and Timothy had come from Macedonia, Paul was compelled by the Spirit (Acts 18:5). In

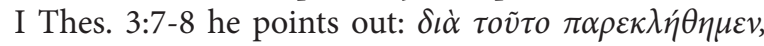

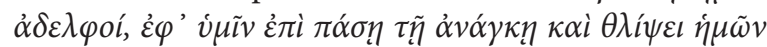

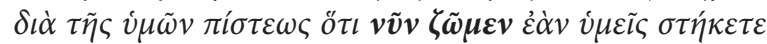
$\dot{\varepsilon} v$ Kvpí $\omega$. The faith (fides) of the Thessalonians towards Paul, his message and the way it was expressed, confirmed that Paul's preaching was not in vein but had $\pi \lambda \eta \rho о \varphi о \rho i \alpha ~ \pi o \lambda \lambda \dot{\eta}$. This had consequences for his self-estimation since it must have rejuvenated Paul who bursts out in thanksgiving which is common in Psalter after a trial. Moreover it must have given him the feeling of spiritual fatherhood and motherhood forging special bonds of friendship. With this psychology he lashes out on (i) the supposedly Greek philosophers (who appeared themselves as doctors of souls) and (ii) intensely on his compatriots, adopting the usual anti-Semitic views of the Greco-roman world, since in Corinth according to Acts he experienced a sundering with the Synagogue (18:4-6). The joy of the apostle was even more because the Thessalonians church with its position was of great importance for the distribution of his preaching since the city not only stood in the midst of via Egnatia, the road that united the West with the 
East but the city also linked the North with the South. By this way the Gospel is preached to every part of the empire, a main presupposition for the coming of the Parousia (Rom. 10:18=Ps.19:4; Mk. 13:10; Mt.24:14):

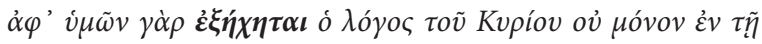

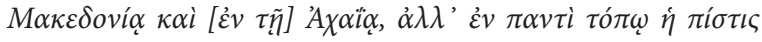

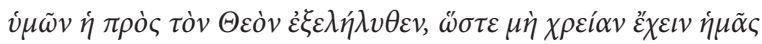
$\lambda \alpha \lambda \varepsilon \tilde{\varepsilon} \nu \tau_{l}(1: 8)$.

2. The Thessalonian church faces sorrows ( $\theta \lambda \dot{\psi} \psi \varepsilon \varepsilon \varsigma)$, which come from outsiders and not from insiders as it will happen in the other epistles (Judeanchristians or 'wise'). The receivers of the epistle are excommunicated from their family-social circle which in the graecoroman pyramid was the most important institution after the religion. So, as underlines Gerber ${ }^{98}$, in the frame of the alternative Ecclesia where it is experienced the principle of the reverse/ inverted pyramid (Mk.10:4245 ) they need to feel love/tenderly care and not an authority which impose his own will. Paul had to conduct according to the image of God the Father and the Lord who was persecuted and dies for us. On the other hand some of the outsiders enemies obviously compared Paul with the itinerant philosophers who through traveling and initiating authorities of the past gained gold and glamour from their preaching taking advantage of the hopes and fears of the people. For these reasons Paul, who during his days as a rabbi he must have been called father and teacher (Mt. 23:10) ${ }^{99}$, let his carefully cultivated father figure not to be distorted into the image of a patriarch ${ }^{100}$ even when he faces the problem of $\pi$ opvia. Yet we have seen from the very beginning he does not accompany his name with servant or apostle of Jesus. He speaks in plural form, not using $I$, while in the epilogue of the epistle he does not refer to any important members of the church. He admits to the worthiness of his audience and rejuvenates their self-esteem using you know repeatedly and the wellknown captatio benevolaentiae of 1:3 but also saying to them that you have no need so that I should write to you, for you yourselves are taught by God to love one another (4:9). The audience themselves have become an example for all the world, as Paul and his associates have become for them (1:6-7). All in all the imitation process revolves around the living and true God, who is called Father and Jesus the Lord who has died for us: And you became followers of us and of the Lord (1:6). Timothy is not characterized as his child but as their brother and minister of God (3:2). That an ostracized people of God doesn't need a new patriarch but a loving family is also seen in the last book of N.T., the Gospel of John where the authority of Peter is called in question. Van der Watt has proved in his Family of the

\footnotetext{
98 Paulus und seine 'Kinder' 338-343.

99 Apparently these three names were quite loved by the Pharisees of the time.

100 As the problem of fornication is dealt with rather harshly in various Judaic texts (see Testaments of the XII Patr.), one could expect Paul to project the similar guiding authority of the father.
}

King: dynamics of metaphor in the Gospel according to John (Leiden 2000) how the metaphor of family (with the elements of love, knowing each other, solicitude, protection) is the constitutive and the most essential imagery in a Gospel which is addressed to Christians expelled from the Synagogue and their families (John 9. 16).

3. Paul's feelings of paternal love and the unique bond he shares with the Thessalonians could be understood according to the fact that they were the firstborn among his children in Christ like the first chosen (by the Apostle himself) associate Timothy who is called his child in 1 Cor. (4:17). We should also remember that according to Acts (16:6-8) before Paul's transition to Macedonia, the Holy Spirit had averted him from preaching in certain parts of Asia Minor and he had already crossed something like 600 miles without any impressive success. We also should not forget that during his visit in Philippi, the first stop he made in European ground, very few believed his word and most of those few were women. Yet with his repeated visits to the city, this Little Rome (probably with Luke's aid who is connected to city of Philippi), he managed to form the Church that would later receive the epistle which is also characterized as a loving-tender one ${ }^{101}$. Paul however doesn't characterize the recipients as $\dot{\alpha} \pi \alpha \rho \chi \eta \dot{~ i n ~ h i s ~ f i r s t ~ e p i s t l e ~}$ as it happens in 2 Thes. $2: 13^{102}$. So this fact is doubtful.

4. On the contrary, Paul seems to be feeling heavily upon him that the coming of the Lord is at hand unlike the false prophets of Pax Romana (see Virgil, IV Ecloge) which in various ways advertised Roma as aeterna and its system as the bearer of peace and security (5:3; comp. Rev. 13). In the light of the Coming of the resurrected Jesus, Paul, who was entrusted to preach to the Gentiles (Gal. 1:16), wants to present all the Christians

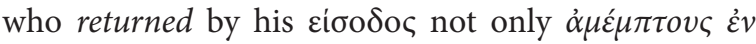
$\alpha \gamma \iota \omega \sigma u ́ v \eta(3: 13) / \delta \lambda \circ \tau \varepsilon \lambda \varepsilon \tilde{\iota} \varsigma$ but also united as a family. So he wants that his letter be read to all the brothers, even those who might not want to really listen. He also invites everybody to kiss each other although he is not giving his own ${ }^{103}$ and in addition he neglects to mention anyone of the $\pi \rho 0 \ddot{\sigma} \sigma \alpha \mu \varepsilon \dot{\varepsilon}$ ovৎ in particular. Through $\varphi \imath \lambda \alpha \delta \varepsilon \lambda \varphi i \alpha$ (whose visual sign was $\alpha \sigma \pi \alpha \sigma \mu o ́ s)$ and the public reading of his epistle which maybe substitutes his holy kiss, they will experience the Grace of the Lord Jesus Christ. Note that it was the coming Caesar that was greeted in a triumphant manner by the crowned members of the local Ecclesia (Greek) often accompa-

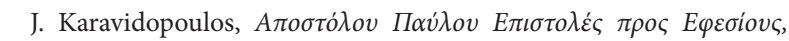

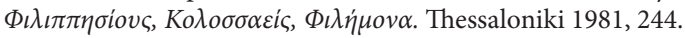

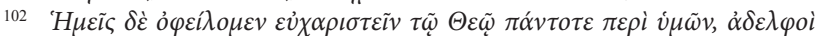

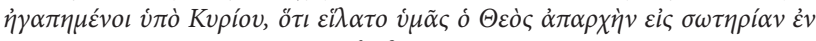

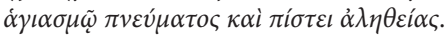

103 The fact that all Christians regardless of ethnicity, gender or status are all brothers sealed with a ritual kiss at the end of the epistle's hearing (probably before the Eucharist where they experienced the union in one body), was a crucial element setting them apart from the other religious parties and Judaism where the term brother also appears but not nearly as vividly as in the Christian Church. 
nied by the whole house (oikos) or school ${ }^{104}$. In this

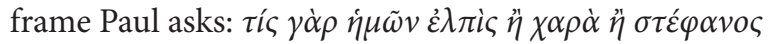

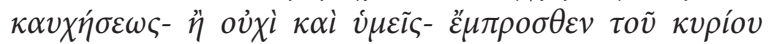

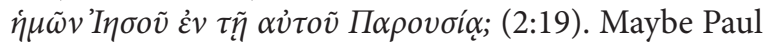
also wanted to shout with Isaiah (8:18): Here am I and the children whom the Lord has given me! $!^{105}$

5. Because of the sentiment that the coming of the Lord is at hand, the epistle itself pictures an apocalyptic and also dualistic way of thought which also requires a powerful family bond so that the battle of the sons of light against the Temper-Satan and his organs can be fought ${ }^{106}$. Characteristic of this apocalyptic way of thought is the coexistence in chap. 2 of passages where it is expressed the extreme love of Paul for his own children with other where he expresses his extreme wrath for his compatriots who persecute him ${ }^{107}$. In this apocalyptic frame Paul aches to make the ostracized Thessalonians understand that they are really his beloved ones. He is also deeply concerned about the sanctification especially of the bodies, an issue which he directly links with the brothers and sisters since

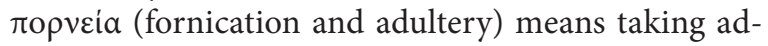
vantage and defrauding one another. Based on archaeological evidence ${ }^{108}$ the cults of Dionysus and Cabei-

\footnotetext{
104 H.S. Versnel, Triumphus: An Inquiry into the Origin, Development and meaning of the Roman Triumph, Leiden: Brill 1970.

105 In the next epistles it feels that the Coming delays, his Churches must be organized and he must defend himself against the false brothers/ tutors. So he appears himself as an authoritative pater familiae.

106 The main prayer of the Christian community, the one that sets it apart from the Synagogue, begins with the word Father and ends with lead us not into temptation but deliver us from evil (Matt 6:13; Luk 11:4).

107 The second subunit of the first part of I Thes. starts with the contrast ${ }^{14}$

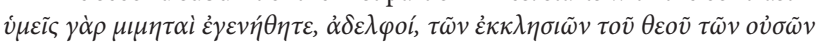

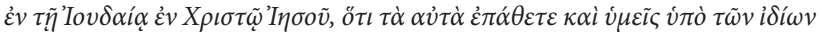

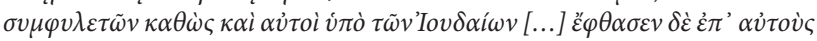

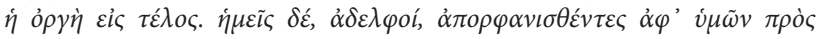

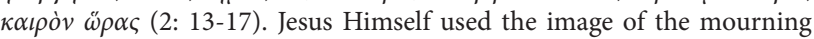
nurse in light of Jerusalem's desolation: "O Jerusalem, Jerusalem, the one who kills the prophets and stones those who are sent to her! How often I wanted to gather your children together, as a hen gathers her brood under her wings, but you were not willing! (Lk. 13:34).

108 See Christoph von Brocke, Thessaloniki - Stadt des Kassander und Gemeinde des Paulus. Eine frühe christliche Gemeinde in ihrer heidnischen Umwelt, WUNT 2- 125; Tübingen 2001. Christopher Steimle, Religion im römischen Thessaloniki, (Studien $u$. Texte zu Antike und Christentum 47), Mohr Siebeck, Tübingen 2008.
}

rus (both worshiped with orgy ceremonies) were quite famous in Thessaloniki at the time. The Thessalonians had returned from the false gods to the one true God and this action probably cost them dearly on their immediate and professional environments ${ }^{109}$. The risk of returning again to their old habits of sin must have been present daily since their isolation of their environment could be "unbearable". To outweigh the traditional abuse of the sexual instinct and the passions of the flesh, Paul feels that he has not only to preach i) the sanctification through abstaining from ropveia and ii) loving one another (something most crucial in order to escape the coming wrath), but also to be bodily near to them, feeling in any case his love/koinonia in practice. Note that (1) at the epilogue 3:12-13 $\tau \dot{0} \sigma \tau \eta \rho i \xi \alpha \iota$

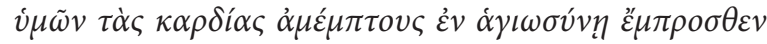
$\tau o \tilde{v} \Theta \varepsilon o \tilde{v}$ (who is named as $\Pi \boldsymbol{\alpha} \tau \dot{\eta} \boldsymbol{\rho} \dot{\boldsymbol{\eta}} \boldsymbol{\mu} \tilde{\boldsymbol{\omega}} \boldsymbol{v}$ ) depends on

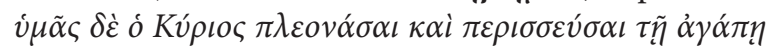

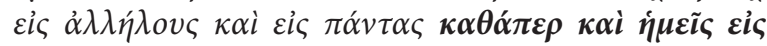

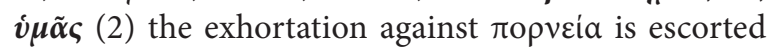
by the parainesis about the $\varphi \iota \lambda \alpha \delta \varepsilon \lambda \varphi i \alpha$. Paul knoes that sexual abuses and the Hagiasmos especially of the body (which in second section attracts his concern) cannot be faced with prohibitions but when his brothers and sisters feel really beloved by a maternal way in the frame of their new family. This is why the apostle desires and prays without ceasing to have face to face communication with them and he presents himself not only as father who teaches with his word and example, but also as the mother who actually when

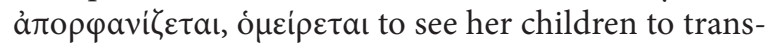
mit them her life. This intimacy and this familiarity will be perfect by the Parousia. This fact for the others means wrath, for the Christians however that they will

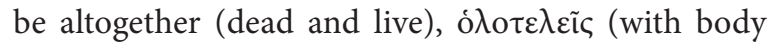

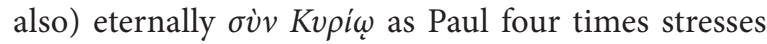
in ch. $4-5(4: 14.17 ; 5: 10)$. This fact differentiates the Pauline eschatology from the other and this must be foreshowed in the Ecclesia which lives 'Ev $\Theta \varepsilon \tilde{\varepsilon} \tilde{\omega} \Pi \alpha \tau \rho i$

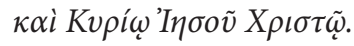

109 With the exception of Musonius Rufus (XII.1-5), the other moralists thought of fornication as not a shameful act.

\section{Bibliography}

Burke T. J., Family Matters: A Socio-Historical Study of Kinship Metaphors in 1 Thessalonians, (JSNTSup 247) London: Sheffield Academic Press 2003.

- Paul's Role as 'Father' to his Corinthian 'Children' in Socio-Historical Context (1 Cor. 4:14-21), in: Paul and the Corinthians: Studies on a Community in Conflict. Essays in Honour of Margaret Thrall. Supplements to Novum Testamentum, ed. Trevor J. Burke and J. Keith Elliott, Leiden: Brill Academic Publishers 2003, p. 95-113.

Caragounis Chrys, Did Paul Behave as an Infant or Imbecile, or as a Gentle
Nurse?, online: http://www.chrys-caragounis.com/Studies/Did\%20 Paul\%20Behave.pdf, 01.08.2014.

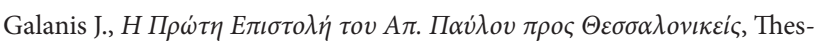
saloniki 1996.

Gerber Christine, Paulus und seine 'Kinder'. Studien zur Beziehungsmetaphorik der paulinischen Briefe (Beihefte zur Zeitschrift für die Neutestamentliche Wissenschaft - BZNW 1360) Berlin-New York: Walter de Gruyter 2005.

Rozmiar artykułu: 2,25 arkusza wydawniczego 